\title{
Partition distribution of selected organochlorine pesticides in water, sediment pore water and surface sediment from uMngeni River, KwaZulu-Natal, South Africa
}

\author{
E Gakuba', B Moodley ${ }^{1 *}$, P Ndungu $^{1,2}$ and G Birungi ${ }^{3}$ \\ ${ }^{1}$ School of Chemistry and Physics, University of KwaZulu-Natal, Westville Campus, Private Bag 45001, Durban 4000, South Africa \\ ${ }^{2}$ Department of Applied Chemistry, Doornfontein Campus, University of Johannesburg, P.O. Box 17011, Doornfontein 2028, \\ Johannesburg, South Africa \\ ${ }^{3}$ Chemistry Department, College of Science, Mbarara University of Science and Technology, P.O Box 1410, Mbarara, Uganda
}

\begin{abstract}
Organochlorine pesticides (OCPs) were analysed in surface water, pore water and surface sediment samples collected from the uMngeni River, which is one of the largest rivers in the province of KwaZulu-Natal, South Africa. Liquid-liquid extraction was used to extract the analytes from water and pore water samples and soxhlet extraction was used to extract sediment samples with subsequent florisil clean-up and gas chromatography-mass spectrometry (GC-MS) analysis. Twelve selected OCPs were analysed and their total concentrations were found to range from $8.04-21.06 \mathrm{ng} / \mathrm{mL}, 36.06-188.43 \mathrm{ng} / \mathrm{mL}$ and $148.17-554.73 \mathrm{ng} / \mathrm{g}$ in unfiltered surface water, unfiltered pore water and surface sediment (dry weight (dw)), respectively. The results indicated that the concentrations of these selected pesticides were far higher in sediment $(72 \%)$ than in pore water $(25 \%)$ and water $(3 \%)$. The most polluted sites were Northern Wastewater Treatment influent $(\mathrm{NWTI})$ for water $\left(\Sigma^{12} \mathrm{OCP}=\right.$ $19.41 \pm 1.43 \mathrm{ng} / \mathrm{mL}$ ) and Northern Wastewater Treatment effluent (NWTE) for pore water $\left(\Sigma^{12} \mathrm{OCP}=166.23 \pm 7.16 \mathrm{ng} / \mathrm{mL}\right.$ ) and sediment $\left(\Sigma^{12} \mathrm{OCP}=495.21 \pm 32.38 \mathrm{ng} / \mathrm{g}\right)$. The most abundant individual OCPs and their average concentrations in general in the river were $p, p^{\prime}$-DDE in unfiltered water $(1.62 \pm 0.22 \mathrm{ng} / \mathrm{mL})$ and unfiltered sediment pore water $(17.09 \pm 7.96 \mathrm{ng} / \mathrm{mL})$, and endrin in surface sediment $(55.57 \pm 19.01 \mathrm{ng} / \mathrm{g}, \mathrm{dw})$.
\end{abstract}

Keywords: uMngeni River, pore water, sediment, organochlorine pesticides, gas chromatography-mass spectrometry

\section{INTRODUCTION}

Pesticides are agrochemicals extensively used in agriculture and public health sectors to control or mitigate pests causing crop damage and diseases. Their main properties include low polarity, low aqueous solubility and high lipophilicity. As a result, they bioaccumulate and bioamplify through the food chain and are hence a threat to the environment and to human health (Afful et al., 2010; ZhaO et al., 2013; Zhao et al., 2009). Researchers have found that organochlorine pesticides and their metabolites may cause chronic toxicity to humans and animals through air, water and food intake (Dong-hui and Guang-xing, 2012; Rachid et al., 2012). Many of them are agents of reproduction and birth defects (Edwards, 1987; Ghuman et al., 2013; Tadevosyan et al., 2012), immune system dysfunction, endocrine disruptions and cause cancer (Adeyemi et al., 2008; Cockburn et al., 2011; Rull and Ritz, 2003). OCPs have been banned in many countries since the 1970s but are still detected in water, sediments, air and aquatic biota today, because of their persistence in the environment (Fox et al., 2001; Albaiges et al., 1987; Iwata et al., 1994; Hogarh et al., 2014).

The uMngeni River has a surface area of $4416 \mathrm{~km}^{2}$ and spans a length of $225 \mathrm{~km}$ from source to mouth. It is the main source of water for many people in this province; both urban and rural and particularly for people living in informal

To whom all correspondence should be addressed.

of +27+27 31 2602796; Fax: +2731 2603091;

e-mail: Moodleyb3@ukzn.ac.za

Received 2 June 2017, accepted in revised form 27 March 2018 settlements along this river who use its untreated water for bathing, cooking, washing, etc. Very limited studies have been carried out on the qualitative and quantitative analysis of pesticides in this river, and this study therefore aims to provide important information on selected pesticides (Fig. 1), their concentrations in the uMngeni River, showing how the pesticides partition themselves between the surface water, sediment pore water and surface sediment, as well as to identify the most highly contaminated sites along the river. In order to determine the total concentrations of pesticides (freely dissolved + organic carbon + suspended solids) to which animals and people using this water are exposed, the water was treated as unfiltered. To the best of our knowledge, this is the first study that has investigated the qualitative and quantitative levels of these selected OCPs from the source to the mouth of the uMngeni River as well as the partitioning of the OCPs between the various environmental matrices. The reported results provide much-needed information on the presence of these OCPs which may contribute to the health risk of animals and humans who consume the water from the uMngeni River, as well as providing information on their partitioning distribution.

\section{MATERIALS AND METHODS}

\section{Chemicals and apparatus}

The solvents including high pressure liquid chromatography (HPLC) grade solvents, namely hexane, dichloromethane (DCM) and toluene, and florisil $\left(\mathrm{MgO}_{3} \mathrm{Si}\right.$ residue analysis grade, mesh $60-100$, pore size $60 \AA$ ), as well as OCP standards 
<smiles>Clc1c(Cl)c(Cl)c([GeH3])c(Cl)c1Cl</smiles>

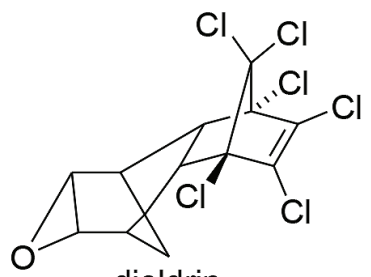

dieldrin<smiles>O=[PH](=O)(O)Oc1ccc(Cl)cc1</smiles>

p.p'-DDD<smiles>ClC1C(Cl)C(Cl)C(Cl)C(Cl)C1Cl</smiles>

$\mathrm{HCH}$<smiles>O=[Po](F)OCc1ccccc1C(=C(Cl)Cl)c1ccc(Cl)cc1</smiles>

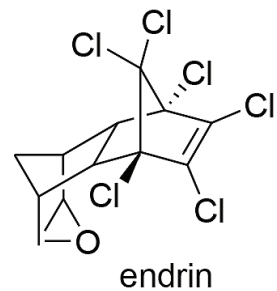<smiles>ClC1=CC2C(Cl)C1(Cl)C1(Cl)C(Cl)=C(Cl)C21Cl</smiles>

Hpchlor<smiles>ClC1=C(Cl)[C@]2(Cl)[C@@H]3C4C=CC(C4)[C@@H]3[C@@]1(Cl)C2(Cl)Cl</smiles>

aldrin<smiles></smiles><smiles>O=[Po]=O</smiles>

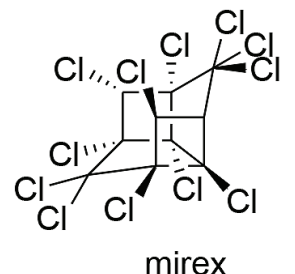

Figure 1

Structures of investigated organochlorine pesticides (OCPS)

(HCB, HCH, heptachlor, aldrin, $o, p-\mathrm{DDE}, p, p^{\prime}-\mathrm{DDE}, o, p-$ DDD, $p, p$-DDD, $o, p$-DDT, dieldrin, endrin, and mirex), which were purchased from Sigma Aldrich. Anhydrous sodium sulfate $\left(\mathrm{Na}_{2} \mathrm{SO}_{4}\right)$ gold line $(\mathrm{CP})$ and silicon carbide boiling stones $(\mathrm{CSi})$ were obtained from Associated Chemical Enterprises (ACE) and sulfuric acid (98\%) was obtained from Promark Chemicals. The test sieves (ss $200 \mathrm{~mm} \varphi \times 100 \mu \mathrm{m}$ to ss $200 \mathrm{~mm} \varphi \times 600 \mu \mathrm{m})$ were obtained from DLD Scientific in South Africa.

\section{Study area}

The uMngeni River is the main river in the province of KwaZulu-Natal and starts from the lower mountains of Spioenkop and Lionskop on either side of Nottingham (Van der Zel, 1975) and ends at the mouth at the Blue Lagoon in Durban which empties into the Indian Ocean. Water and sediment samples were collected during the winter period, from 15 to 17 July 2013, from 15 sampling stations including 12 sites selected along the uMngeni River and 3 sites around the Northern Wastewater Treatment Works (NWWTW), which discharges its treated water back into the uMngeni River a few kilometres downstream. Sampling stations were selected based on their location and activities around them, such as agricultural, industrial or residential. The environmental physical parameters, coordinates and map of the sampling area are shown in Table 1 and Fig. 2.

\section{Sampling}

Water samples were collected in 2.5 L Winchester amber bottles previously washed with hot water and detergent and rinsed 3 times with sulfuric acid and deionized water, respectively.
At the site, the bottles were washed 3 times with the river water to be sampled. After sample collection, the bottles were sealed with caps lined with aluminium foil. Sediment samples were collected at the same sites as the water samples using a grab sampler and stored in glass bottles washed and capped as aforementioned. Water and sediment sample bottles were kept in a portable ice chest containing ice while they were transported to the laboratory. Water samples were acidified with $1 \mathrm{~mL}$ of $\mathrm{H}_{2} \mathrm{SO}_{4}(50 \% \mathrm{v} / \mathrm{v})$ to prevent microbiological degradation and stored in a refrigerator at $4^{\circ} \mathrm{C}$ until extraction, which followed within 3 days. The sediment samples were centrifuged (Du pont instruments ${ }^{\mathrm{R}} \mathrm{SS}$-automatic centrifuge) using $10 \times 1000 \mathrm{r} / \mathrm{min}$ for $15 \mathrm{~min}$ to separate the sediment from the pore water (Ankley and Schubauer-Berigan, 1994; Zhang et al., 2003), and thereafter transferred onto aluminium foil for air drying. The pore water obtained was treated as per surface water samples.

\section{Sample extraction and clean-up}

Water samples were extracted using liquid-liquid extraction as per EPA method 3510C (EPA, 1996). A $1 \mathrm{~L}$ aliquot of the water sample was transferred to a separatory funnel and extracted with $50 \mathrm{~mL}$ of DCM. The organic layer was removed and the process repeated 6 times for the same sample using fresh DCM aliquots each time in order to increase recovery. The six fractions of extracts were combined and concentrated to approximately $5 \mathrm{~mL}$ using a rotavap (Heidolph Instruments $\mathrm{GmbH} \& \mathrm{Co.kG}$ ). The concentrated extract was quantitatively transferred onto a florisil (activated at $130^{\circ} \mathrm{C}$ for $12 \mathrm{~h}$ ) column containing anhydrous $\mathrm{Na}_{2} \mathrm{SO}_{4}(5 \mathrm{~g})$ on top for clean-up. The column was eluted with increasing polarity mixtures of hexane-DCM (5 mL each) (94:6), (85:15), (50:50) and 100\% 


\begin{tabular}{|c|c|c|c|c|c|c|c|}
\hline \multicolumn{8}{|c|}{$\begin{array}{l}\text { TABLE } 1 \\
\text { Physical and chemical parameters and geographical coordinates of the sampling sites during winter } 2013\end{array}$} \\
\hline \multirow{2}{*}{ Sampling site } & \multirow{2}{*}{$\begin{array}{l}\text { Ambient } \mathrm{T}^{\circ} \\
\left({ }^{\circ} \mathrm{C}\right)\end{array}$} & \multirow{2}{*}{$\begin{array}{c}\text { Water } \mathrm{T}^{\circ} \\
\left({ }^{\circ} \mathrm{C}\right)\end{array}$} & \multirow{2}{*}{$\mathrm{pH}$} & \multirow{2}{*}{$\begin{array}{c}\begin{array}{c}\text { Conductivity } \\
(\mu \mathrm{s} / \mathrm{cm})\end{array} \\
\end{array}$} & \multirow{2}{*}{$\begin{array}{c}\text { TDS } \\
(\mathrm{mg} / \mathrm{L})\end{array}$} & \multicolumn{2}{|c|}{ Coordinates } \\
\hline & & & & & & South & East \\
\hline Midmar Dam inlet (MDI) & 12.3 & 11.6 & 5.54 & 83.7 & 49 & $2929^{\prime} 16.05^{\prime \prime}$ & $3009^{\prime} 23.10^{\prime \prime}$ \\
\hline Midmar Dam outlet (MDO) & 12.3 & 13.2 & 5.69 & 75.5 & 44 & $2929^{\prime} 34.02^{\prime \prime}$ & $3012^{\prime} 09.13^{\prime}$ \\
\hline Howick Falls (HOF) & 17.8 & 13.8 & 5.99 & 89.7 & 53 & $2929^{\prime} 18.18^{\prime \prime}$ & $3014^{\prime} 19.70^{\prime \prime}$ \\
\hline Albert Falls inlet (AFI) & 18.6 & 13.5 & 5.78 & 111.5 & 65 & $2926^{\prime} 31.94^{\prime \prime}$ & $3019^{\prime} 47.10^{\prime \prime}$ \\
\hline Albert Falls outlet (AFO) & 19.2 & 15.4 & 6.04 & 93.8 & 55 & $2926^{\prime} 01.81^{\prime \prime}$ & $3025^{\prime} 55.76^{\prime \prime}$ \\
\hline Nagle Dam (NAD) & 18.4 & 15.4 & 5.00 & 114.0 & 66 & $2935^{\prime} 08.42^{\prime \prime}$ & $3037^{\prime} 23.94^{\prime \prime}$ \\
\hline $\begin{array}{l}\text { Joining point uMngeni- } \\
\text { Msunduzi Rivers (JUM) }\end{array}$ & 15.6 & 15.7 & 5.56 & 367.0 & 214 & $2937^{\prime} 16.61^{\prime \prime}$ & $3040^{\prime} 46.59^{\prime \prime}$ \\
\hline Inanda Dam inlet (IDI & 17.2 & 16.6 & 4.98 & 278.0 & 160 & $2939^{\prime} 05.20^{\prime \prime}$ & $3048^{\prime} 06.24^{\prime \prime}$ \\
\hline Inanda Dam outlet (IDO) & 15.1 & 15.9 & 4.53 & 257.0 & 149 & $2942^{\prime} 55.74^{\prime \prime}$ & $3052^{\prime} 07.69^{\prime \prime}$ \\
\hline Reservoir Hills (REH) & 21.4 & 17.9 & 5.63 & 305.0 & 176 & $2947^{\prime} 08.05^{\prime \prime}$ & $3056^{\prime} 25.51^{\prime \prime}$ \\
\hline Umgeni Business Park (UBP) & 21.4 & 17.6 & 4.90 & 334.0 & 194 & $2948^{\prime} 19.05^{\prime \prime}$ & $3058^{\prime} 58.08^{\prime \prime}$ \\
\hline $\begin{array}{l}\text { Northern Wastewater Treatment } \\
\text { Works influent (NWTI) }\end{array}$ & 22.8 & 21.9 & 4.70 & 970.0 & 568 & $29^{\circ} 47^{\prime} 47.08^{\prime \prime}$ & $30^{\circ} 59^{\prime} 50.01^{\prime \prime}$ \\
\hline $\begin{array}{l}\text { Northern Wastewater Treatment } \\
\text { Works after treatment (NWTT) }\end{array}$ & 19.8 & 19.9 & 4.64 & 1238 & 719 & $29^{\circ} 47^{\prime} 47.02^{\prime \prime}$ & $30^{\circ} 59^{\prime} 50.06^{\prime \prime}$ \\
\hline $\begin{array}{l}\text { Northern Wastewater Treatment } \\
\text { Works effluent (NWTE) }\end{array}$ & 21.0 & 19.8 & 4.94 & 674 & 392 & $29^{\circ} 48^{\prime} 27.01^{\prime \prime}$ & $30^{\circ} 59^{\prime} 51.05^{\prime \prime}$ \\
\hline Blue Lagoon (BLA) & 21.4 & 20.0 & 5.12 & $--^{a}$ & - & $2948^{\prime} 41.03^{\prime \prime}$ & $3102^{\prime} 12.05^{\prime \prime}$ \\
\hline
\end{tabular}

a Blue lagoon is located at the mouth of the river where it empties in Indian ocean, the conductivity and TDS were higher than the maximum the instrument could measure

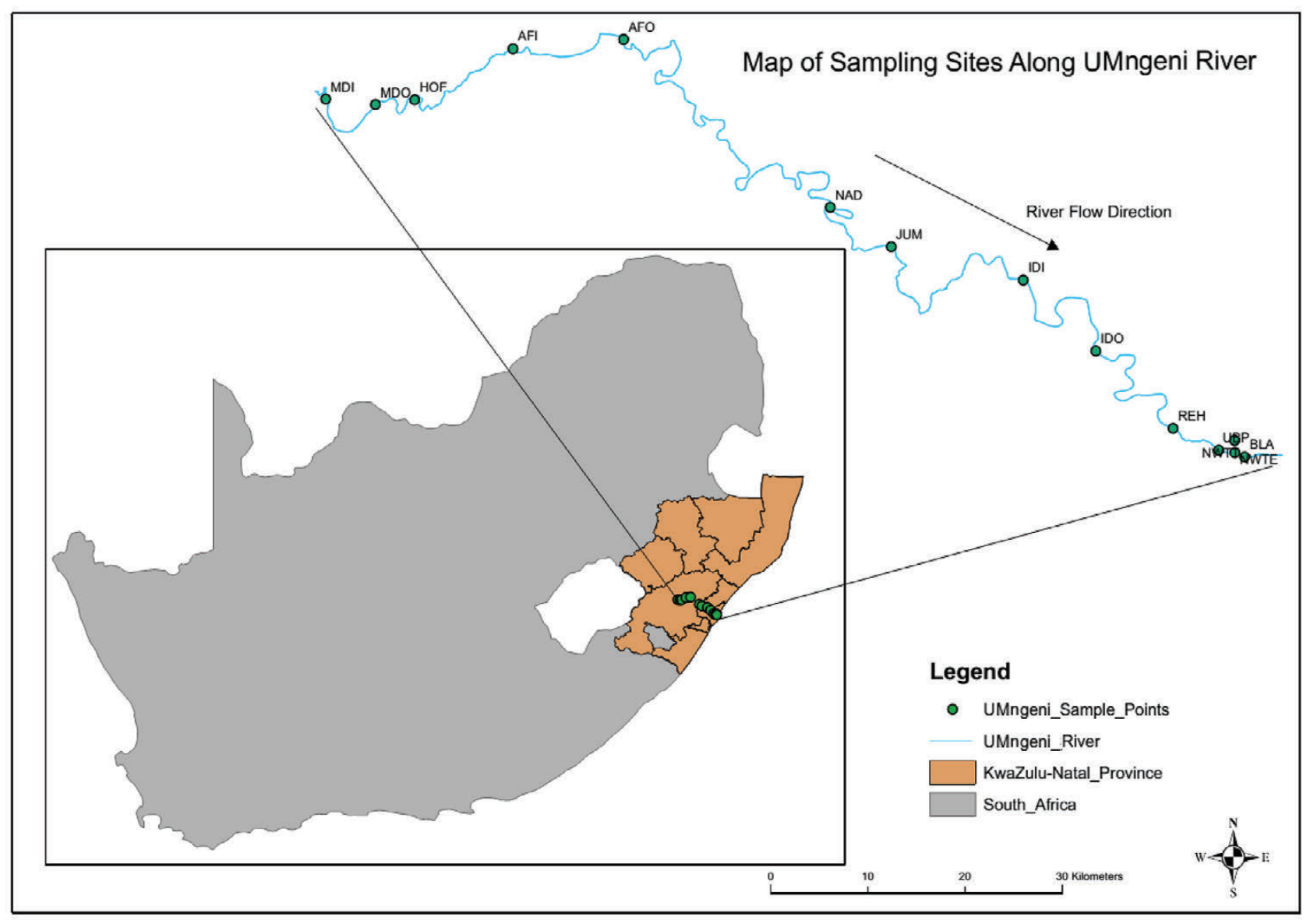

Figure 2

Map of sampling sites with the sample collection locations (map was generated from GPS coordinates using ArcGIS 10.2) 


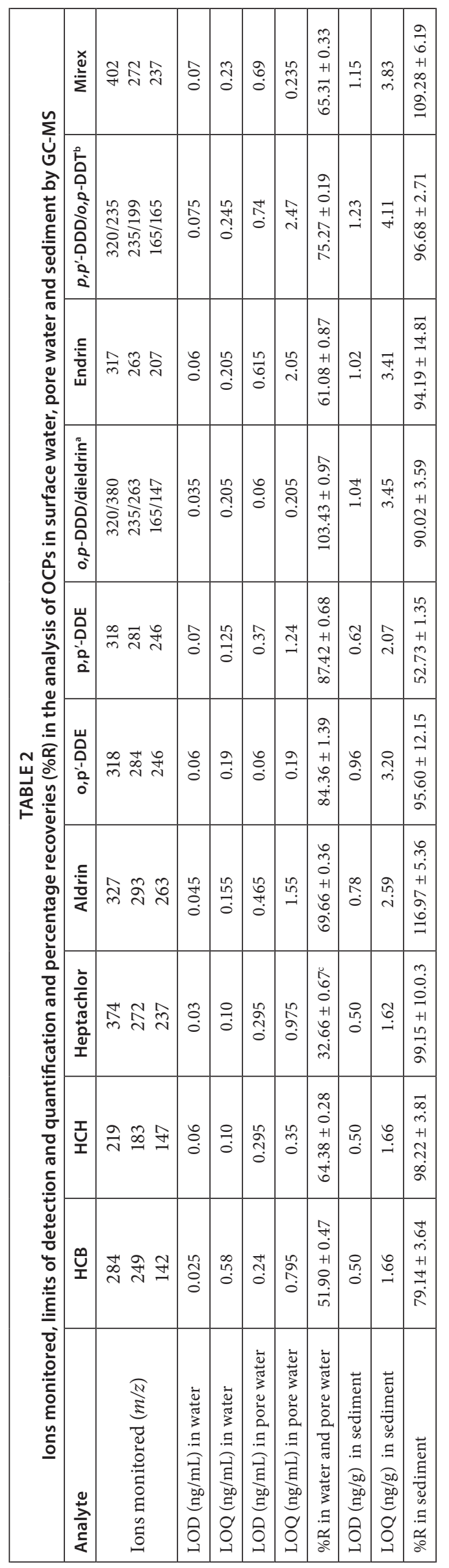

DCM (modified EPA method 3620-C) (EPA, 2007) in order to elute different OCPs with varying polarity indices. The four fractions were combined and concentrated using rotary evaporation to nearly $5 \mathrm{~mL}$, then air-dried and reconstituted to $2 \mathrm{~mL}$ and analysed using GC-MS. The pore water obtained after centrifugation of the sediment was treated as the water samples above using $100 \mathrm{~mL}$ of the sample and $10 \mathrm{~mL}$ of DCM. The sediment samples were air-dried, ground and sieved for homogenization and to increase the surface area. A $60 \mathrm{~g}$ sample of dry sediment was extracted with $300 \mathrm{~mL}$ of toluene in a soxhlet extraction unit for $24 \mathrm{~h}$. Toluene is a suitable solvent for aromatic compounds such as organochlorine pesticides because of its similar polarity, and research has shown it to be one of the most efficient solvents for extraction of these compounds (OleszekKudlak et al., 2007). The resulting extract was concentrated using a rotavap for subsequent clean-up. The clean-up procedure was carried out as described for the water and pore water samples using a $20 \mathrm{~mL}$ mixture of hexane and DCM. The sediment extract was concentrated to $2 \mathrm{~mL}$ and analysed with GC-MS.

\section{Sample analysis}

Sample analyses were carried out in triplicate using an Agilent 6890 series gas chromatography system attached to a mass spectrometer detector (MSD5973). The GC system was equipped with a ZB-5MS capillary column, $0.25 \mathrm{~mm}$ i.d., $0.25 \mu \mathrm{m}$ film thickness and $30 \mathrm{~m}$ length (Hewlett Packard; Houston, TX). The MS was operated using the selective ion monitoring acquisition mode (SIM). The carrier gas was purified helium. Splitless mode was used to inject $2 \mu \mathrm{L}$ of sample onto the GC column with injector and detector temperatures set at 250 and $280^{\circ} \mathrm{C}$, respectively. The oven temperature was programmed from $120^{\circ} \mathrm{C}$, increased to $290^{\circ} \mathrm{C}$ with a ramping rate of $14^{\circ} \mathrm{C} / \mathrm{min}$ and held for $2 \mathrm{~min}$. The MS source was operated at $250^{\circ} \mathrm{C}$ and quad at $200^{\circ} \mathrm{C}$. The electro energy was $70 \mathrm{eV}$.

Target analytes were quantified based on peak areas and by using an external calibration technique with the following 6 calibration standards: $0.25 ; 0.5 ; 1 ; 2 ; 4 ; 8 \mathrm{ng} / \mathrm{mL}$. The identification of the analytes of interest was achieved by using mass spectral data compared to that found in the National Institute of Standards and Technology (NIST) library and comparison of retention times of analytes with those of reference standards. The identification was also carried out using the base peak and two other confirming ions (Table 2 and Fig. A2 in the Appendix).

\section{QUALITY CONTROL}

The extraction recoveries (R) and limits of detection (LOD) and quantification (LOQ) for each analyte in each matrix were calculated (Table 2 ). Recoveries $\left(\mathrm{R}_{1}\right)$ were obtained by spiking tap water (Agunbiade and Moodley, 2014; Meharg et al., 2003) with pesticide standards which were extracted using the method described above for water and pore water samples, and per cent recoveries $\left(\% R_{1}\right)$ were obtained by calculating the ratio between the concentration found $\left(C_{f}\right)$ and the concentration spiked $\left(C_{s}\right)$, multiplied by 100 (Eq. A1 in Appendix.) (APHA et al., 1999, USEPA, 2008). For sediment sample analyte recoveries $\left(R_{2}\right)$, real sediment samples were subdivided into two subsamples whereby one was spiked with OCP standards before extraction, while the other was left unspiked and both extracted and analysed. The $\% R_{2}$ was obtained by subtracting the concentration of unspiked subsample $\left(C_{u}\right)$ from the 
concentration of the spiked subsample $(C)$, divided by the known concentration spiked $\left(C_{k}\right)$ and the result was multiplied by 100 (Eq. A2 in Appendix) (Harry et al., 2008). The recovery studies were carried out in triplicate and the mean recovery and the standard deviation were calculated for each analyte. The actual samples were also analysed in triplicate to measure the reproducibility and precision of the method used. The limit of detection and quantification were calculated as 3 times and 10 times, respectively, the signal-to-noise ratio, using the standard deviation of 3 calibration intercepts divided by the slope. Procedural blanks were used through all phases of extraction and analysis. The analytes of interest were not detected in the blank samples. The solvent blanks and pesticide standards were regularly run on the GC-MS to ensure that there were no interferences in the GC system. A check was done, by running a calibration standard of $0.5 \mathrm{mg} / \mathrm{mL}$ after each batch of sample, to ensure that the variation from the initial calibration standards was minimal. All data were processed using Microsoft Excel (version 2010).

\section{RESULTS AND DISCUSSION}

\section{Levels of organochlorine pesticide residues in surface water}

The distribution of the OCPs in water from the 15 sampling sites revealed a broad and diverse range of fluctuations (Fig. 3a

TABLE 3

\begin{tabular}{|c|c|c|c|c|c|c|c|c|c|}
\hline \multicolumn{10}{|c|}{$\begin{array}{l}\text { TABLE } 3 \\
\text { Total concentrations of OCPs }(\mathrm{ng} / \mathrm{mL} \text { or } \mathrm{ng} / \mathrm{g}) \text { in water pore water and sediment of uMngeni River }\end{array}$} \\
\hline \multirow{2}{*}{ Analyte } & \multicolumn{3}{|c|}{ water $(\mathrm{ng} / \mathrm{mL})$} & \multicolumn{3}{|c|}{ pore water $(\mathrm{ng} / \mathrm{mL})$} & \multicolumn{3}{|c|}{ sediment $(n g / g, d w)$} \\
\hline & range & mean & SD & range & mean & SD & range & mean & SD \\
\hline НСB & $0.41-1.04$ & 0.63 & 0.1 & $1.06-6.08$ & 3.11 & 0.43 & $2.29-49.44$ & 13.18 & 1.56 \\
\hline $\mathrm{HCH}$ & $0.50-1.97$ & 0.82 & 0.2 & $0.76-6.80$ & 3.69 & 0.4 & $4.34-93.02$ & 40.95 & 3.4 \\
\hline heptachlor & $0.32-2.07$ & 0.66 & 0.13 & $2.19-12.63$ & 7.37 & 0.85 & $18.46-50.77$ & 30.43 & 4.76 \\
\hline aldrin & $0.01-2.73$ & 1.2 & 0.11 & $4.11-21.96$ & 12.61 & 0.77 & $8.27-37.80$ & 22.29 & 4.27 \\
\hline$o, p^{\prime}-\mathrm{DDE}$ & $1.21-2.32$ & 1.5 & 0.1 & $5.18-24.39$ & 14.79 & 0.88 & $17.78-50.70$ & 26.27 & 2.05 \\
\hline$p, p^{\prime}-\mathrm{DDE}$ & $1.34-2.01$ & 1.62 & 0.07 & $5.73-27.93$ & 17.09 & 0.92 & $20.61-38.72$ & 27.57 & 1.97 \\
\hline$o, p^{\prime}$-DDD/dieldrin & $1.41-1.99$ & 1.69 & 0.1 & $7.15-34.92$ & 20.53 & 1.25 & $22.97-34.46$ & 27.07 & 1.33 \\
\hline endrin & $0.88-3.48$ & 1.39 & 0.12 & $4.07-19.21$ & 10.38 & 1.09 & $28.10-87.72$ & 55.57 & 4.27 \\
\hline$p, p^{\prime}-\mathrm{DDD} / o, p^{\prime}-\mathrm{DDT}$ & $1.23-1.72$ & 1.39 & 0.1 & $3.37-22.34$ & 13.22 & 0.99 & $18.51-33.44$ & 23.14 & 1.1 \\
\hline mirex & $0.74-1.74$ & 1.02 & 0.08 & $2.47-12.18$ & 7.28 & 0.77 & $6.83-78.66$ & 42.23 & 2.94 \\
\hline$\Sigma O C P s$ & $8.04-21.06$ & 11.92 & 1.12 & $36.06-188.43$ & 110.09 & 8.35 & 148.17-554.73 & 308.7 & 3.05 \\
\hline
\end{tabular}
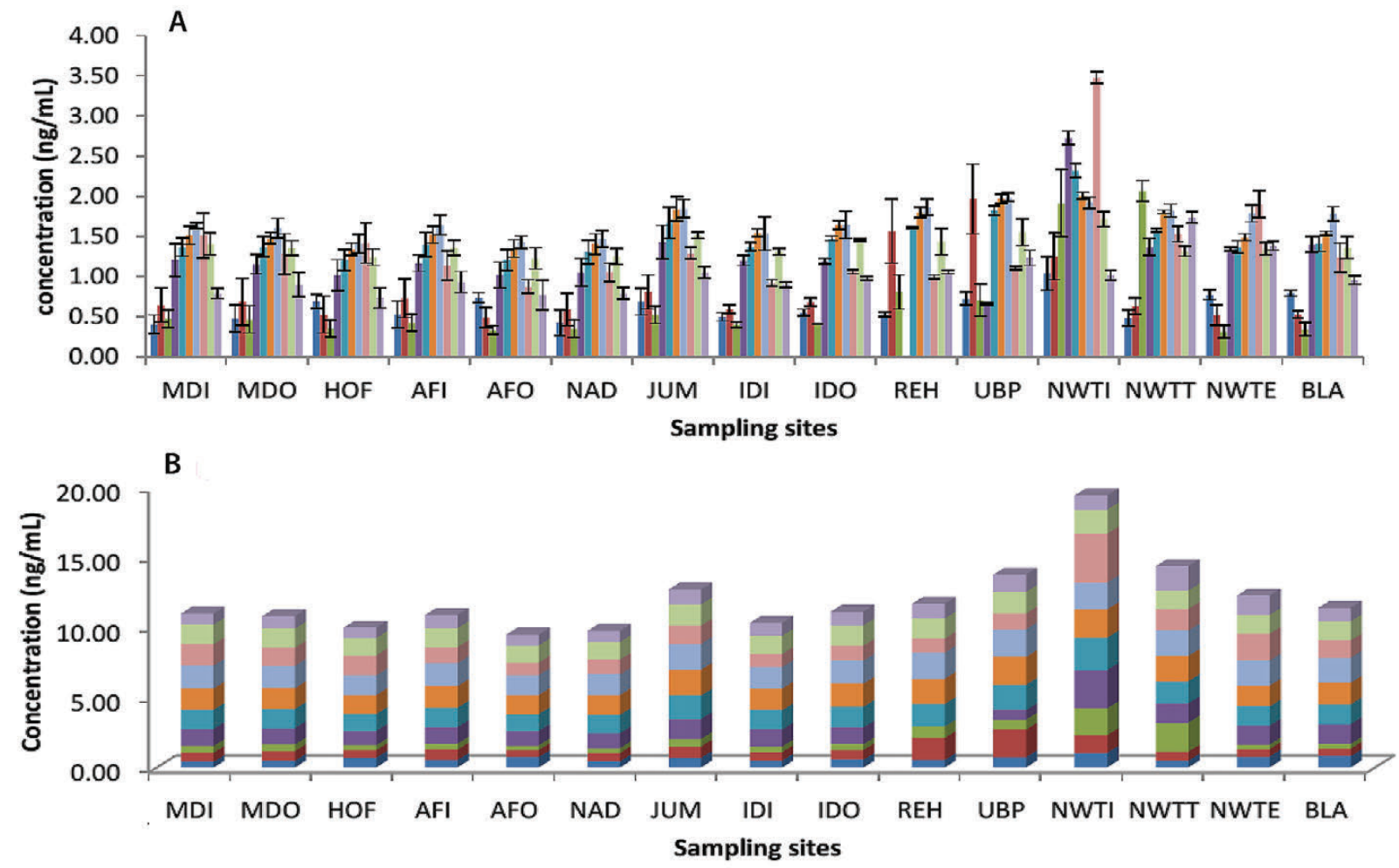

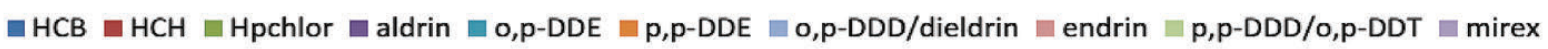

Figure 3

a) Individual OCP concentrations b) Total concentration of OCPs in water samples at each site 
and b; Table 3). The concentrations of individual pesticides ranged from a non-detectable level for aldrin at Reservoir Hills (REH) to $3.48 \mathrm{ng} / \mathrm{mL}$ for endrin at Northern Wastewater Treatment Works influent (NWTI). The levels of pesticides were higher at the sites surrounding the wastewater treatment works and the point of discharge into the uMngeni River. Researchers have found that wastewater treatment plants can be considered as a source point of persistent organic pollutants (Samara et al., 2006).

The results showed that $o, p^{\prime}$-DDE and $p, p^{\prime}$-DDE were among the main OCPs in the uMngeni River water, with average concentrations of 1.50 and $1.62 \mathrm{ng} / \mathrm{mL}$, respectively. The presence of these DDT degradation products suggest that DDT was the common pesticide in use before it was banned in 1983 in South Africa. Thereafter, DDT was allowed to be used in a controlled manner only by Government, for the purpose of malaria control (Rother and Jacobs, 2008), and therefore may be present in foodstuff such as meat, fish, and vegetables transported from DDT-affected areas (McHugh et al., 2011), such as Limpopo and Mpumalanga (Dalvie et al., 2004b; Dalvie et al., 2004a; Naudé and Rohwer, 2012; Van Dyk et al., 2010), to the area investigated in this study. A study by Batterman and coworkers found that many of the OCPs investigated in this study were also found in air samples collected in the Durban city area close to where the uMngeni River passes before it reaches the Indian Ocean (Batterman, 2008). Furthermore, during cooler temperatures, OCPs have the ability to re-condense from air and enter waterways, especially during the winter period when these samples were collected (Scheringer et al., 2004; Lohmann et al., 2007; Valle et al., 2007).

As the river flows from IDI towards the mouth of the river, the concentration rose to $19.41 \mathrm{ng} / \mathrm{mL}$ at NWTI. The high concentration at NWTI was expected because it receives untreated wastewater, which has a high organic matter content, to which the OCPs partition which results in high OCP concentrations (Kile et al., 1995). The Northern Wastewater Treatment Works (NWWTW) does reduce the concentrations of the analysed pesticides to some extent, as relatively lower concentrations were found for the water sample collected after treatment (NWTT). Table A1 in the Appendix shows the extent to which the individual OCPs were removed from wastewater during the treatment process. Another phenomenon, which may have reduced the concentrations of OCPs in water at NWTT, is their settling into the bio-solids.

The settling of the OCPs onto the biosolids was probably due to a very low flow rate of water in the holding pond area, before being sent to the point of discharge into the river. This allowed the organic matter to settle into the sediment; thus the reason for the higher total concentrations in sediment pore water and sediment than in water. After NWTT the concentration decreases due to dilution of OCPs as they are discharged into the river.

The increase in total concentration of OCPs may also be explained by the physical parameters that were recorded during the sampling trip. The higher concentration of total suspended solids and total dissolved solids is an indication of pollution (Mahananda et al., 2010), and the higher the conductivity, the higher the TDS. Figure A3 and Tables 1 and A2 (Appendix), show some increase in total dissolved solids and conductivity from the source at MDI (TDS $=49 \mathrm{mg} / \mathrm{L}$, conductivity $=83.7 \mu \mathrm{s} / \mathrm{cm})$ to NAD $(66 \mathrm{mg} / \mathrm{L}, 114.0 \mu \mathrm{s} / \mathrm{cm})$, with the corresponding total OCP concentrations ranging from $9.47 \pm 1.13$ to $10.99 \pm 1.39 \mathrm{ng} / \mathrm{mL}$ (Fig. A4). However, at JUM, the values of TDS and conductivity increased considerably, to $214.0 \mathrm{mg} / \mathrm{L}$ and $367.0 \mu \mathrm{s} / \mathrm{cm}$, respectively (Fig. A3). The significant increase in TDS and conductivity corresponds to the large increase in OCP concentration at that site $(12.69 \mathrm{ng} / \mathrm{L})$, which can be explained by the high preference of the OCPs to adsorb onto the dissolved organic matter (high TDS) at this site. The second portion of the river, from IDI to NWTI, had the highest values for TDS $(568.0 \mathrm{mg} / \mathrm{L})$ and conductivity $(970.0 \mu \mathrm{s} / \mathrm{cm})$, which correspond to the highest total OCP concentration $(19.41 \mathrm{ng} / \mathrm{mL})$ at NWTI. Figures $3 \mathrm{~b}$ and A4 show a decrease in total concentration of OCPs in the section from NWTI to BLA, which is attributed to dilution effects because the treated water is discharged into the uMngeni River at NWTE. Moreover, Waziri and Ogugubuaja (2010) demonstrated a positive correlation between levels of pollution indicators in the River Yobe, Nigeria, such as between total organic carbon (TOC) and biochemical oxygen demand (BOD), on the one hand, and between BOD and TDS, on the other; therefore there was a positive correlation between levels of TOC and TDS in the river (Waziri and Ogugbuaja, 2010). Samples with high TDS values (Figure A3) are therefore expected to have correspondingly high TOC values, as shown by Waziri and Ogugbuaja (2010). Research has also shown that there is a strong affinity between organic carbon and hydrophobic compounds that have high $\log K_{\text {ow }}$ values, such as organochlorine pesticides (Luo et al., 2009), which ranged from 3.73 to 6.93 for the selected OCPs in this study. Since in the present study water samples that were unfiltered were analysed in order to determine the concentrations of OCPs that humans and animals were exposed to by direct consumption, they were expected to contain high levels of organic carbon; hence the reason for the presence of high concentrations of total OCPs observed at AFI, JUM and NWTI (Figs 3b and A4).

Table A1 (Appendix) shows that most OCP concentrations were reduced, with the highest reduction observed for endrin at $56.03 \%$ and the lowest reduction for DDD/dieldrin at $5.21 \%$. This may also suggest that the NWWTW pollutant concentrations vary considerably throughout the day, depending on the type of effluent received. A further detailed investigation is needed of the NWWTW water purification process in order to understand how, why and to what extent the treatment procedure selectively reduces some OCP concentrations and not others. Previous studies on wastewater treatment plants have shown that POPs are generally present in higher concentrations in the influent than the effluent (Mowery and Loganathan, 2007).

\section{Levels of organochloride pesticide residues in pore water}

The results obtained for OCP concentrations in pore water are shown in Tables 3 and A3 and Figs $4 \mathrm{a}$ and b. The levels of individual OCPs varied from $0.76 \pm 0.01$ to $34.92 \pm 4.01 \mathrm{ng} / \mathrm{mL}$. The total concentration of OCPs in pore water was 10 times higher than in surface water. This may be explained by the low solubility of these OCPs in surface water and preference for adsorption onto organic matter, because of the strong affinity that exists between OCPs and colloids in sediment pore water. As a result these OCPs tend to have long-term deposition and accumulation in sediment (Josefsson, 2011 ).

There was a general increase in concentration of OCPs in pore water from the source to the mouth of the river. This corresponded to an increase in TDS and conductivity in water in the same direction (Mahananda et al., 2010). Once again the increase of TDS downstream implies an increase of TOC (Waziri 
and Ogugbuaja, 2010), which allowed the pesticides to partition to it and hence resulted in the increased concentrations downstream as well. OCPs could possibly suspend themselves on these types of solid particles in water and may sink down to the sediment and re-suspend themselves in sediment pore water (Zhang et al., 2003). Research has shown that solid particles such as plastic resin pellets and broken bits of plastics from consumers are good carriers of persistent organic pollutants, which are sorbed onto them in the affected waterways (Moore et al., 2004; Mato et al., 2001). The downstream organic pollutant accumulation effect observed in pore water in this study resembles that reported by Marie-Jeanne et al. (2014), who found the same effect for organic contaminants such as PCBs, PBDs and phthalates in sediment of the Seine River in France. The downstream Seine River concentrations increased 69-fold, 25-fold and 11-fold respectively for BDE 209, $\Sigma$ tri-hexa $\mathrm{BDE}$ and $\sum 7 \mathrm{PCBs}$, compared to upstream concentrations (MarieJeanne et al., 2014).

The highest mean concentration of individual contaminants across all sampling sites was: $o, p$-DDE $-14.79 \pm 0.88 \mathrm{ng} / \mathrm{mL}$, $p, p^{\prime}-\mathrm{DDE}-17.09 \pm 0.92 \mathrm{ng} / \mathrm{mL}$, endrin $-10.38 \pm 1.09 \mathrm{ng} / \mathrm{mL}$ and aldrin $-12.61 \pm 0.77 \mathrm{ng} / \mathrm{mL}$ in pore water samples. It was observed that the concentration was reduced at Blue Lagoon (mouth of the river) which may be due to dilution effects because of the close proximity of the Indian Ocean at that site.

The highest total concentration of OCPs was observed at NWTE (166.23 ng/mL, 12\%), NWTT (162.88 ng/mL, 11\%), IDO (162.88 ng/mL, 11\%), UBP (141.22 ng/mL, 10\%), REH (140.18 ng/mL, 10\%) and IDI (128.30 ng/mL, 9\%) (Fig. A6). The high OCP concentrations at the REH site is of concern as this sampling site is a few kilometres upstream of an informal settlement whose residents may be exposed to these OCPs if they collect their drinking water too close to the sediment, as the OCPs can re-suspend into the water column (Chau, 2006, Elena et al., 2011).

\section{Levels of organochlorine pesticide residues in sediments}

The OCPs investigated were detected in the sediment samples from all sites. The total concentrations of pesticides at each site are shown in Table A4 and Fig. 5b, and varied from $183.63-495.21 \mathrm{ng} / \mathrm{g}$, with an average concentration of $308.70 \mathrm{ng} / \mathrm{g}$. The highest concentrations of pesticides were obtained at NWTT $(495.21 \mathrm{ng} / \mathrm{g} \pm 32.38,11 \%)$, BLA $(417.49 \pm 23.58 \mathrm{ng} / \mathrm{g}, 9 \%)$ and HOF $(353.39 \pm 41.71 \mathrm{ng} / \mathrm{g}$, $8 \%$ ). The analysis of bio-solids collected from NWTT (postchlorination) (11\%) showed a higher concentration than that collected from NWTI (before process treatment) (7\%) (Fig. A8). A possible explanation could be that at NWTT, the pollutants from the WWTW accumulated over years in the bio-solid at the bottom of the pit where treated water is held before being discharged, while at NWTI, the bio-solid collected was not allowed to accumulate over long periods but was regularly removed from the influent water. As the treated water flows towards the point of discharge (NWTE), the total concentration of pesticides decreased from NWTT to NWTE because the sediment at this sampling point is now from the flowing river and the OCPs do not have sufficient time to partition to the sediment as compared to when they are in the holding pond. The levels of OCPs in sediments were higher than in river water and in pore water.
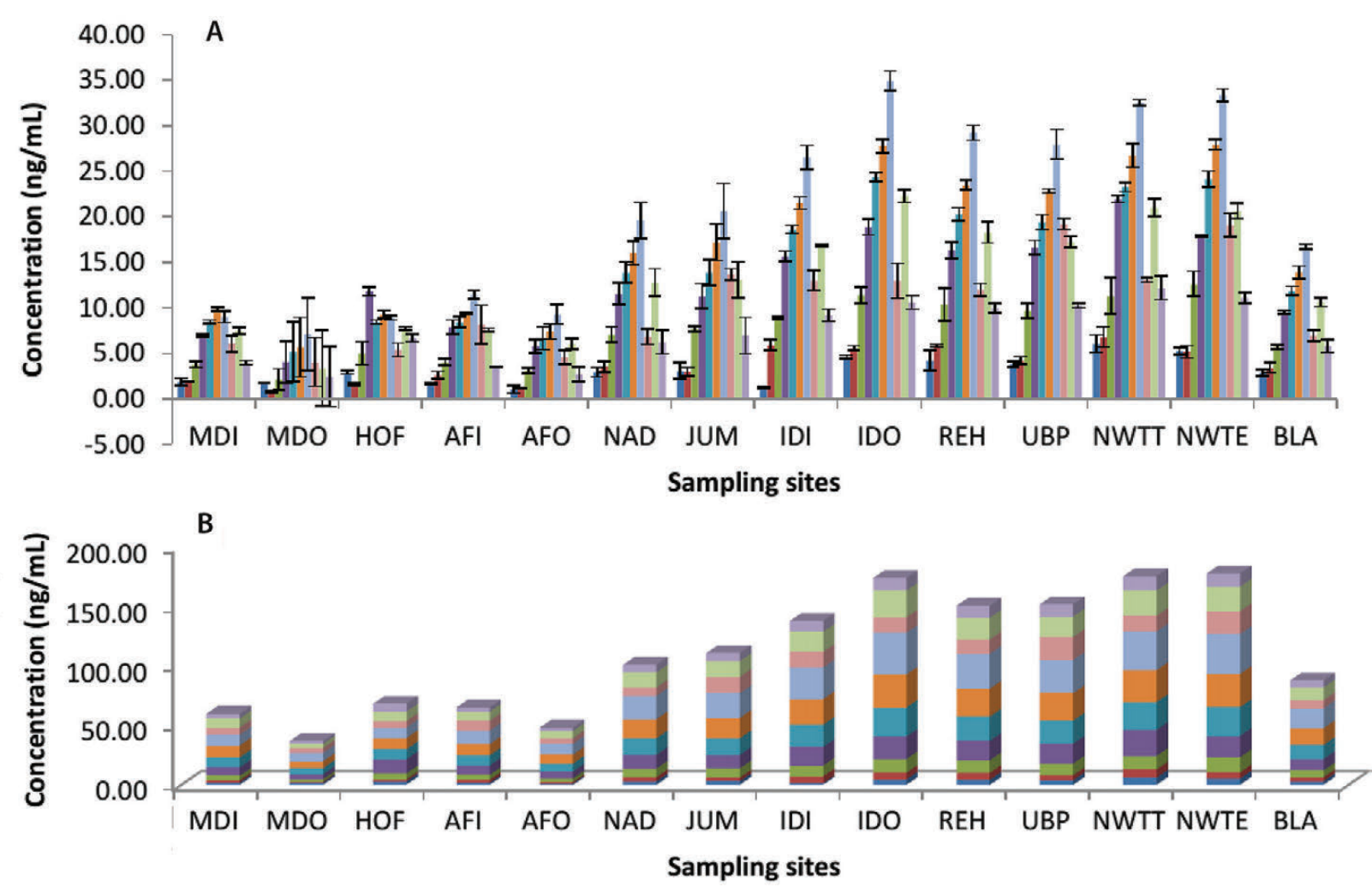

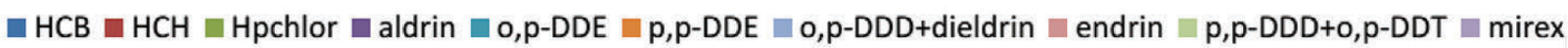

Figure 4

a) Concentrations of individual OCPs in pore water b) Total concentrations of OCPs at each site 
This was expected since POPs are known to prefer partitioning to organic material in sediment rather than dissolving in water (Zhou and Rowland, 1997). The sedimentpore water distribution model of POPs has shown that they occur in higher concentrations in sediment than in pore water (Perssona et al., 2005). The concentration of $\mathrm{HCH}$ in the sediment of the uMngeni River (4.34-93.02 ng/g, dw) was higher than levels of $\mathrm{HCH}$ observed in the sediments of Qinhe River (nd-13.72 ng/g) in China (Fei et al., 2013). However, the individual levels of OCPs in uMngeni River sediments (2.29$93.02 \mathrm{ng} / \mathrm{g}$ ), were comparable to individual levels in 4 rivers running through an intensive agricultural area in Kilimanjaro in Tanzania (nd-132 ng/g) (Hellar-Kihampa, 2011). The levels in this study were below the results obtained from water $(0.1-48.6 \mathrm{ng} / \mathrm{mL})$ and sediment $(0.10-163.00 \mathrm{ng} / \mathrm{g})$ collected from the Densu River basin in Ghana (Kuranchie-Mensah et al., 2012).

\section{Total mean concentration of OCPs in water, pore water and sediment}

The total concentrations and mean values of 12 pesticides investigated in water, sediment pore water and surface sediment are shown in Table 3. The total concentrations ranged from 8.04 to $21.06 \mathrm{ng} / \mathrm{mL}$, with a mean of $11.92 \pm 1.12$ $\mathrm{ng} / \mathrm{mL}$ for water, and 36.06 to $188.43 \mathrm{ng} / \mathrm{mL}$ with a mean of $110.09 \pm 8.35 \mathrm{ng} / \mathrm{mL}$ for sediment pore water. The overall concentration of the pesticides in surface sediments varied from 148.17 to $554.73 \mathrm{ng} / \mathrm{g}$, with a mean concentration of $308.07 \pm 3.05 \mathrm{ng} / \mathrm{g}, \mathrm{dw}$ (Table 3). These total concentrations of OCPs observed in the sediment of uMngeni River were higher than those found in surface sediment from the Yamuna River in Dehli, India ( $\Sigma^{20} \mathrm{OCP} 157.71-307.66 \mathrm{ng} / \mathrm{g}$ ), and observed in the pre-monsoon season (Pandey et al., 2011). However, results of the present study were similar to those obtained by Pandey for sediment of the Yamuna River (195.86-577.74 $\mathrm{ng} / \mathrm{g}$ ) in the monsoon season, and lower than those obtained during the post-monsoon season (306.9-844.45 ng/g,dw) (Pandey et al., 2011). The comparison of the results of the present study with other results obtained elsewhere in South Africa showed that the levels of OCPs in the uMngeni River water were higher than the levels detected in sediment (trace$184 \mathrm{ng} / \mathrm{g}$ ) of freshwater systems in the Eastern Cape (Fatoki and Awofolu, 2003b). However, the uMngeni River was much less polluted by OCPs than the Jukskei River catchment area in Gauteng, where OCP levels varied from 0.895 to $9089 \mathrm{ng} /$ $\mathrm{mL}$ in unfiltered water and from 0.266 to $22914 \mathrm{ng} / \mathrm{g}$, dw in sediments (Sibali et al., 2008).

Figures A9 and A10 show that the concentrations of OCPs in water were less than in pore water and much less than in the sediments. This was expected because the organochlorine pesticides are non-polar and hydrophobic and may only dissolve partially in water while sediment is considered as a sink for them (Noegrohati et al., 2008; Houde et al., 2008; Miglioranza et al., 2004). Currently there are no South African guidelines or regulations to direct the environmental POPs levels in South Africa. Compared to Canadian Sediment Quality guidelines, the levels of $\mathrm{HCB}(2.29-49.44 \mathrm{ng} / \mathrm{g}), \mathrm{HCH}$ (4.34-93.02 ng/g), $o, p^{\prime}-\mathrm{DDE}(17.78-50.70 \mathrm{ng} / \mathrm{g})$, and $p, p^{\prime}-\mathrm{DDE}$ (20.61-38.72) in this study of the uMngeni River were higher than the interim freshwater sediment quality guidelines (ISQG)
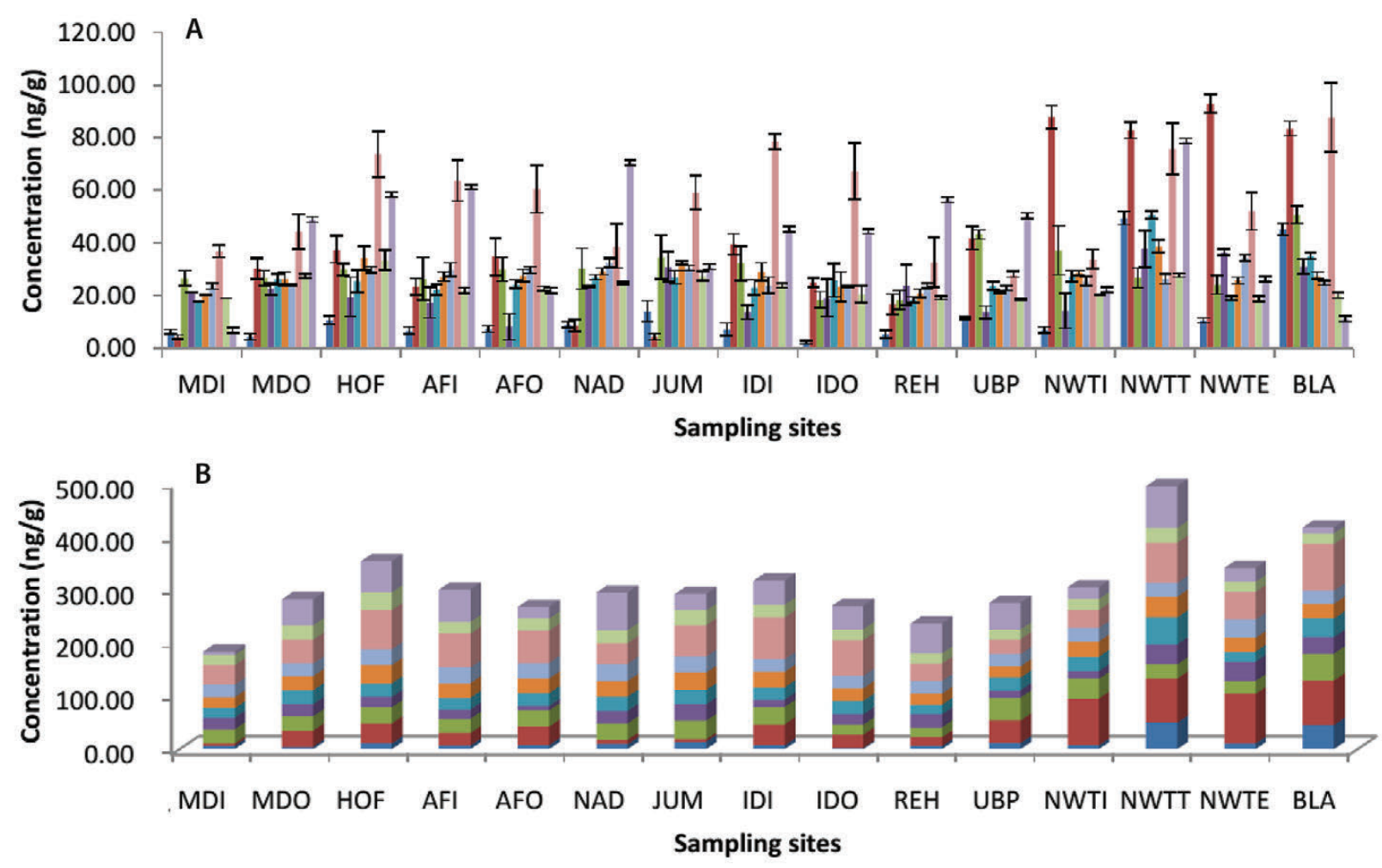

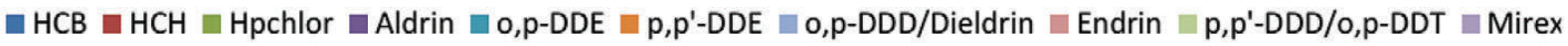

Figure 5

a) Individual OCP concentrations in sediment at different sites along the river b) Total concentrations ( $\mathrm{ng} / \mathrm{g}$ ) of OCPs in sediment 
(HCB: $0.940 \mathrm{ng} / \mathrm{g}),(\mathrm{HCH}: 0.600 \mathrm{ng} / \mathrm{g}),\left(o, p^{\prime}-\mathrm{DDE}\right.$ and $p, p^{\prime}-\mathrm{DDE}$ : $1.420 \mathrm{ng} / \mathrm{g}$ ) and Probable Effect Level (PEL) (HCB:1.380 ng/g, HCH: $2.740 \mathrm{ng} / \mathrm{g}, o, p^{\prime}$-DDE, $p, p^{\prime}$-DDE: $6.750 \mathrm{ng} / \mathrm{g}$ ) (CCME, 2002). Compared to Ontario Sediment Quality Guidelines, the HCB level in this study was lower than its Lowest Effect Levels (LEL) (20 ng/g), except at the NWTT (49.44 ng/g) and BLA (45.26 ng/g) sites. The other above-mentioned OCP levels were higher than their LEL values (HCB: $20 \mathrm{ng} / \mathrm{g}$ ). However, the levels of the aforesaid OCPs at all sites, in the current study, were far below their severe effect level (SEL) (HCB: 24000 ng/g, HCH: $12.000 \mathrm{ng} / \mathrm{g}, o, p^{\prime}-\mathrm{DDE}$ and $p, p^{\prime}-\mathrm{DDE}: 19.000 \mathrm{ng} / \mathrm{g}$ ) according to the Ontario Sediment Quality Guidelines (Persaud et al., 1993). A review done by Burton on the sediment guidelines in use around the world showed that PEL in sediment for $p, p^{\prime}$-DDE, $p, p^{\prime}$-DDD and endrin are $6.8,8.51$ and $1.38 \mathrm{ng} / \mathrm{g}$ (Burton, 2002), which are lower than the results obtained in this study.

\section{CONCLUSION}

The present study has provided data on levels of organochlorine pesticides in surface water, sediment pore water and sediments of the uMngeni River in KwaZulu-Natal, South Africa. All 12 selected pesticides investigated were detected at all sites, in water, pore water and sediment, except aldrin which was below the limit of detection in water at the Reservoir Hills sampling site. The levels of organochlorine pesticides in sediment were higher than in pore water and much higher than in surface water, confirming the preferred partitioning of OCPs to organic matter, which is highest in sediment compared to water. The present study showed that the discharge from the wastewater treatment plant increased the concentrations of organochlorine pesticides in the river, for water, pore water and sediment samples collected at the sites close to the NWWTW. Hence, discharges from this WWTP may be considered as one of the sources of pollutants such as OCPs in the uMngeni River. $p, p^{\prime}$-DDE was found to be the pollutant with the highest concentrations in water and pore water and endrin that with the highest concentrations in sediment of the uMngeni River. These results provide important information on the present levels of selected OCPs in a Southern African environment, despite OCP use and production being banned in this region, though some OCPs have regulated use for malaria control. In the future, studies on POPs in the sediment of this river should focus on their distribution according to particle sizes of the sediment and comparison of depth and surface sediment concentrations.

\section{ACKNOWLEDGEMENTS}

The authors would like to thank the University of KwaZuluNatal, and the Water Research Commission of South Africa (Project No. K5/2215/3) for financial support. We also wish to thank the School of Chemistry and Physics for use of the analytical instrumentation. We are grateful to the lab technicians for their assistance, especially Mrs Anita Naidoo and $\mathrm{Mr}$ Neal Broomhead for providing useful lessons on the use of analytical instruments.

\section{REFERENCES}

ADEYEMI D, UKPO G, ANYAKORA C and UNYIMADU JP (2008) Organochlorine pesticide residues in fish samples from Lagos Lagoon, Nigeria. Am. J. Environ. Sci. 4 (6) 649-653. https://doi, org/10.3844/ajessp.2008.649.653
AFFUL S, ANIM AK and SERFORAR-ARMAH Y (2010) Spectrum of organochlorine pesticide residues in fish samples from Densu Basin. Res. J. Environ. Earth Sci. 2 (3) 133-138.

AGUNBIADE FO and MOODLEY B (2014) Pharmaceuticals as emerging organic contaminants in Umgeni River water system, KwaZulu-Natal, South Africa. Environ. Monit. Assess. $1867273-$ 7291. https://doi.org/10.1007/s10661-014-3926-z

ALBAIGES J, FARRAN A, SOLER M, GALLIFA A and MARTIN $P$ (1987) Accumulation and distribution of biogenic and pollutant hydrocarbons, PCB's and DDT in tissues of western mediterranean fishes. Mar. Environ. Res. 22 (1) 1-18. https://doi. org/10.1016/0141-1136(87)90078-X

ANKLEY GT and SCHUBAUER-BERIGAN MK (1994) Comparison of techniques for the isolation of sediment pore water for toxicity testing. Arch. Environ. Con. Tox. 27 (4) 507-512. https://doi. org/10.1007/bf00214842

APHA, AWWA and WEF (1999) Standard methods for the examination of water and wastewater [Electronic version]. American Public Health Association; American Water Works Association and Water Environmental Association. URL: http:// www.mwa.co.th/download/file_upload/SMWW_1000-3000.pdf. (Accessed 4 August 2014)

BATTERMAN SA, CHEMYAK SM, GOUNDEN Y, MATOOANE M and NAIDOO RN (2008) Organochlorine pesticides in ambient air in Durban, South Africa. Sci. Total Environ. 397 119-130.

BURTON GA (2002) Sediment quality criteria in use around the world. Limnology 3 (2) 65-75. https://doi.org/10.1007/s102010200008

CCME (2002) Canadian sediment quality guidelines for the protection of aquatic Life [Electronic version]. Canadian Council of Ministers of the Environment. URL: http://www.pla.co.uk/Environment/ Canadian-Sediment-Quality-Guidelines-for-the-Protection-ofAquatic-Life (Accessed 29 August 2014).

CHAU KW (2006) Persistent organic pollution characterization of sediments in Pearl River estuary. Chemosphere 64 (9) 1545-1549. https://doi.org/10.1016/j.chemosphere.2005.11.060

COCKBURN M, MILLS P, ZHANG X, ZADNICK J, GOLDBERG D and RITZ B (2011) Prostate cancer and ambient pesticides exposure in agriculturally intensive area of in california. Am. J. Epidemiol. 173 (11) 1280-1288. https://doi.org/10.1093/aje/kwr003

DALVIE MA, MYERS JE, THOMPSON ML, ROBINS TG, DYER S, RIEBOW J, MOLEKWA J, JEEBHAY M, MILLAR R and KRUGER $\mathrm{P}$ (2004a) The long-term effects of DDT exposure on semen, fertility, and sexual function of malaria vector-control workers in Limpopo Province, South Africa. Environ. Res. 96 (1) 1-8. https:// doi.org/10.1016/j.envres.2003.09.002

DALVIE MA, MYERS JE, THOMPSON ML, ROBINS TG, OMAR $S$ and RIEBOW J (2004b) Exploration of different methods for measuring DDT exposure among malaria vector-control workers in Limpopo Province, South Africa. Environ. Res. 96 (1) 20-27. https://doi.org/10.1016/j.envres.2003.09.004

DONG-HUI X and GUANG-XING L (2012) Acute and chronic toxic effects of DDT on Pseudodiaptomus poplesia. Chin. J. Ecol. 31 882-887.

EDWARDS CA (1987) The environmental impact of pesticides. Parasitis 86 309-329.

ELENA DD, ANGELA M, DANIELA G, MARIA M, GIUSEPPINA G, ANTONINO N, ALESSIA DA, MARGHERITA F, MARIa VB and SALVATORE F (2011) Effects of "in vivo" exposure to toxic sediments on juveniles of sea bass (Dicentrarchus labrax). Aquat. Toxicol. 105 688-697. https://doi.org/10.1016/j.aquatox.2011.08.026

EPA (1996) Method 3510 C: Separatory funnel liquid-liquid extraction [Electronic version]. URL: http://www.epa.gov/osw/hazard/ testmethods/sw846/pdfs/3510c.pdf (Accessed 9 August 2014).

EPA (2007) Method 3620: Florisil cleanup [Electronic version]. URL: http://www.epa.gov/osw/hazard/testmethods/sw846/pdfs/3620c. pdf (Accessed 10 March 2014).

FATOKI OS and AWOFOLU OR (2003b) Persistent organochlorine pesticides residues in freshwater systems and sediments from the Eastern Cape, SA. Water SA 29 323-330.

FEI W, PENG F, XIUPING M, WEIXIN J and LAN W (2013) Distribution of organochlorine pesticides along the Qinhe River and its risk evaluation. Chin. J. Appl. Environ. Biol. 19 670-676. https://doi.org/10.3724/SP.J.1145.2013.00670 
FOX WM, CONNOR L, COPPLESTONE D, JOHANSON MS and LEAH RT (2001) The organochlorine contamination history of the mersey estuary, UK revealed by analysis of sediment cores from salts marshes. Environ. Res. 51 213-227. https://doi.org/10.1016/ s0141-1136(00)00093-3

GHUMAN SPS, RATNAKARAN U, BEDI JS and GILL JPS (2013) Impact of pesticide residues on fertility of dairy animals: a review. Indian J. Anim. Sci. 83 1243-1255.

HARRY BM, LYNN SW and JUDITH AS (2008) Alternative approches to collecting and interpreting matrix spike data. 27th Annual EPA Conference on Managing Environmental Quality Systems [Electronic version]. URL: http://www.epa.gov/QUALITY/qs-2008/ alternative.pdf (Accessed 12 June 2014).

HELLAR-KIHAMPA H (2011) Pesticide residues in four rivers running through an intensive agricultural area, Kilimanjaro, Tanzania. J. Appl. Sci. Environ. Manage. 15 (2) 307-316.

HOGARH JN, SEIKE N, KOBARA Y, OFOSU-BUDU GK, CARBOO D and MASUNAGA S (2014) Atmospheric burden of organochlorine pesticides in Ghana. Chemosphere 102 1-5. https:// doi.org/10.1016/j.chemosphere.2013.10.019

HOUDE M, MUIR DCG, KIDD KA, GUILDFORD S, DROUILLARD K, EVANS MS, WANG X, WHITTLE DM., HAFFNER D and KLING H (2008) Influence of lake characteristics on the biomagnification of persistent organic pollutants in lake trout food webs. Environ. Toxicol. Chem. 27 2169-2178. https://doi. org/10.1897/08-071.1

IWATA H, TANABE S, SAKAI N, NISHIMURA A and TATSUKAWA $R$ (19940) Distribution of persistent organochlorines in the oceanic air and surface sea water and the role of ocean on their global transport and fate. Environ. Pollut. 85 15-33. https://doi. org/10.1016/0269-7491(94)90234-8

JAHANGIR AM, DAOXIAN Y, YONG JUN J, YUCHUAN S, LI $Y$ and XU X (2014) Sources and transports of organochlorine pesticides in the Nanshan underground river, China. Environ. Earth Sci. 71 1977-1987. https://doi.org/10.1007/s12665-013-2919-5

JOSEFSSON S (2011) Fate and transport of POPs in the aquatic environment - with focus on contaminated sediments. $\mathrm{PhD}$ dissertation, Umeå University.

KURANCHIE-MENSAH H, ATIEMO S, PALM L, BLANKSONARTHUR S, TUTU A and FOSU P (2012) Pesticide residues in water and sediment from the Densu River basin in Ghana. Chemosphere 86 286-292. https://doi.org/10.1016/j. chemosphere.2011.10.031

LOHMANN R, BREIVIK K, DACHS J and MUIR D (2007) Global fate of POPs: Current and future research directions. Environ. Pollut. 150 150-165. https://doi.org/10.1016/j.envpol.2007.06.051

LUO J, MA M, LIU C, ZHA J and WANG Z (2009) Impacts of particulate organic carbon and dissolved organic carbon on removal of polycyclic aromatic hydrocarbons, organochlorine pesticides, and nonylphenols in a wetland. J. Soil Sediment 9 180-187. https://doi.org/10.1007/s11368-009-0081-1

MAHANANDA MR, MOHANTY BP and BEHERA NR (2010) Physical chemical analysis of surface and ground water of Bargarh district, Orissa. Ind. Int. J. Res. Rev. Appl. Sci. 2 284-295.

MARI-JEANNE T, KHAWLA T, MARTINE B, PIERRE L, FABRICE A and MARC C (2014) Polychlorinated biphenyls, polybrominated diphenyl ethers, and phthalates in roach from the Seine River basin (France): impact of densely urbanized areas. Arch. Environ. Con. Tox. 66 41-57. https://doi.org/10.1007/s00244-013-9955-8

MATO Y, ISOBE T, TAKADA H, KANEHIRO H, OHTAKE C and KAMINUMA T (2001) Plastic resin pellets as a transport medium for toxic chemicals in the marine environment. Environ. Sci. Technol. 35 318-324. https://doi.org/10.1021/es0010498

MCHUGH KJ, SMIT NJ, VAN VUREN JHJ, VAN DYK JC, BERVOETS L, COVACI A and WEPENER V (2011) A histologybased fish health assessment of the tigerfish, Hydrocynus vittatus from a DDT-affected area. Phys. Chem. Earth A/B/C 36 895-904. https://doi.org/10.1016/j.pce.2011.07.077

MEHARG AA, WRIGHT J, LEEKS GJL, WASS PD, OWENS P N, WALLING D E and OSBORN D (2003) PCB congener dynamics in a heavily industrialized river catchment. Sci. Total Environ. 314-316 439-450. https://doi.org/10.1016/S0048-9697(03)00067-6 MIGLIORANZA K S B, AIZPUN de MORENO JE and MORENO V
J (2004) Land-based sources of marine pollution: organochlorine pesticides in stream systems. Environ. Sci. Pollut. Res. 11 227-232. https://doi.org/10.1007/BF02979630

MOORE CJ, LATTIN G L and ZELLERS A F (2004) A brief analysis of organic pollutants sorbed to pre and post production of pastic particles from the Los Angeles and San Gabriel River watershads. Algalita Marine Research Foundation, Long Beach, CA.

MOWERY H R and LOGANATHAN BG (2007) Persistent organic compounds in wastewater: azithromycin and urobilin concentrations in wastewater treatment plant samples from Murray, Kentucky, USA [Electronic version]. Department of Chemistry and Center for Reservoir Research, Murray State University, Murray, KY. URL: http://campus.murraystate.edu/services/URSA/FINAL_ PAPER_Holly_Mowery.pdf (Accessed 19 August 2014).

NAUDE Y and ROHWER ER (2012) Novel method for determining DDT in vapour and particulate phases within contaminated indoor air in a malaria area of South Africa. Anal. Chim. Acta 730 112-119. https://doi.org/10.1016/j.aca.2012.02.054

NOEGROHATI S, NARSITO N, SAPTONO H and SANJAYADI S (2008) Fate and behavior of organochlorine pesticides in the Indonesian tropical climate: a study in the Segara Anakan estuarine ecosystem. Clean Soil Air Water 36 767-774. https://doi. org/10.1002/clen.200800083

OLESZEK-KUDLAK S, SHIBATA E, NAKAMURA T, LI X W, YUA YM and DONGA XD (2007) Review of the sampling and pretreatment methods for dioxins determination in solids, liquids and gases. $J$. Chin. Chem. Soc. 54 245-262. https://doi.org/10.1002/jccs.200700037

PANDEY P, KHILLARE PS and KUMAR K (2011) Assessment of organochlorine pesticide residues in the surface sediments of River Yamuna in Delhi India. J. Environ. Prot. 2 511-524. https://doi. org/10.4236/jep.2011.25059

PERSAUD D, JAAGUMAGI R and HAYTON A (1993) Guidelines for the protection and management of aquatic sediment quality in ontario [Electronic version]. Ontario Ministry Of Environment \& Energy. Standard Development Branch and Environmental Monitoring and Reporting Branch. URL: http://www.itrcweb. org/contseds-bioavailability/References/guide_aquatic_sed93.pdf (Accessed 29 August 2014).

PERSONNA N J, BUCHELIA T D, GUSTAFSSONA Ö, BROMANA D, NAESB K, ISHAQA R and ZEBUHRA Y (2005) Testing common sediment-porewater distribution models for their ability to predict dissolved concentrations of POPs in The Grenlandsfjords, Norway. Chemosphere 59 1475-1485. https://doi.org/10.1016/j. chemosphere.2004.08.040

RACHID M, PAULE V and HLIMA B (2012) Chronic toxicity of chlordane to Daphnia magna and Ceriodaphnia dubia: A comparative study. Environ. Toxicol. 279097.

ROTHER HA and JACOBS R (2008) Pesticide health risk for South African emerging farmers [Electronic version]. Surplus People Project (SPP), Cape Town. URL: http://www.spp.org.za/booklets/ pesticide_booklet.pdf (Accessed 26 June 2014).

RULL RP and RITZ B (2003) Historical pesticide exposure in California using pesticide use reports and land-use surveys : an assessment of misclassification error and bias. Environ. Health Persp. 111 1582-1589. https://doi.org/10.1289/ehp.6118

SAMARA F, TSAI CW and AGA DS (2006) Determination of potential sources of PCBs and PBDEs in sediments of Niagara River. Environ. Pollut. 139 489-497.

SCHERINGER M, SALZMANN M, STROEBE M, WEGMANN F, FENNER K and HUNGRBHLER K (2004). Long-range transport and global fractionation of POPs: insights from multimedia modeling studies. Environ. Pollut. 128 177-188. https://doi. org/10.1016/j.envpol.2003.08.027

SIBALI LL, OKWONKWO JO and MCCRINDLE RI (2008) Determination of selected organochlorine pesticide (OCP) compounds from the Jukskei River catchment area in Gauteng, South Africa. Water SA 34 611-621.

TADEVOSYAN NS, MURADYAN SA, TADEVOSYAN A E, KHACHATRYAN BG, DZHANDZHAPANYAN A N, PARSADANYAN G G, POGOSYAN SB, GEVORKYAN NB and GULOYAN AA (2012). Monitoring of environmental pollution in Armenia and certain issues on reproductive health and cytogenetic status of organism. Gigiena i Sanitariiâ 5 48-53. 
USEPA (United States Environmental Protection Agency) (2008) Method 1668B: Chlorinated biphenyl congeners in water, soil, sediment, biosolids, and tissue by HRGC/HRMS. Quantitative determination. USEPA, Washington, DC.

VALLE MD, CODATO E and MARCOMINIA A (2007) Climate change influence on POPs distribution and fate: A case study. Chemosphere 67 1287-1295. https://doi.org/10.1016/j. chemosphere.2006.12.028

VAN DER ZEL DW (1975) Umgeni River catchment analysis. Water SA 1 70-75.

VAN DYK JC, BOUWMAN H, BARNHORN IE J and BORNMAN M (2010) DDT contamination from indoor residual spraying for malaria control. Sci. Total Environ. 408 2745-2752. https://oi. org/10.1016/j.scitotenv.2010.03.002

WAZIRI M and OGUGBUAJA VO (2010) Interrelationships between physicochemical water pollution indicators: A case study of River Yobe-Nigeria. Am. J. Sci. Ind. Res. 1 76-80.
ZHANG ZL, HONG HS, ZHOU JL, HUANG J and YU J (2003) Fate and assessment of persistent organic pollutants in water and sediment from Minjiang River Estuary, Southeast China. Chemosphere, 52 1423-1430. https://doi.org/10.1016/ S0045-6535(03)00478-8

ZHAO Z, ZHANG L, WU J and FAN C (2009) Distribution and bioaccumulation of organochlorine pesticides in surface sediments and benthic organisms from Taihu Lake, China. Chemosphere 77 1191-1198. https://doi.org/10.1016/j.chemosphere.2009.09.022

ZHAO Z, ZHANG L, WU J and FAN C (2013) Residual levels, tissue distribution and risk assessment of organochlorine pesticides (OCPs) in edible fiches from Taihu Lake, China. Environ. Monit. Assess. 185 9265-9277. https://doi.org/10.1007/s10661-013-3249-5

ZHOU JL and ROWLAND S J (1997) Evaluation of the interactions between hydrophobic organic pollutants and suspended particles in estuarine waters. Water Res. 31 1708-1718. https://doi. org/10.1016/S0043-1354(96)00323-5 


\section{APPENDIX}

\section{Equations}

$\% R_{1}=\left(C_{\mathrm{f}} / C_{\mathrm{s}}\right) \times 100$

$\% R_{2}=\left[\left(C_{\mathrm{s}}-C_{\mathrm{u}}\right) / C_{\mathrm{k}}\right] \times 100$
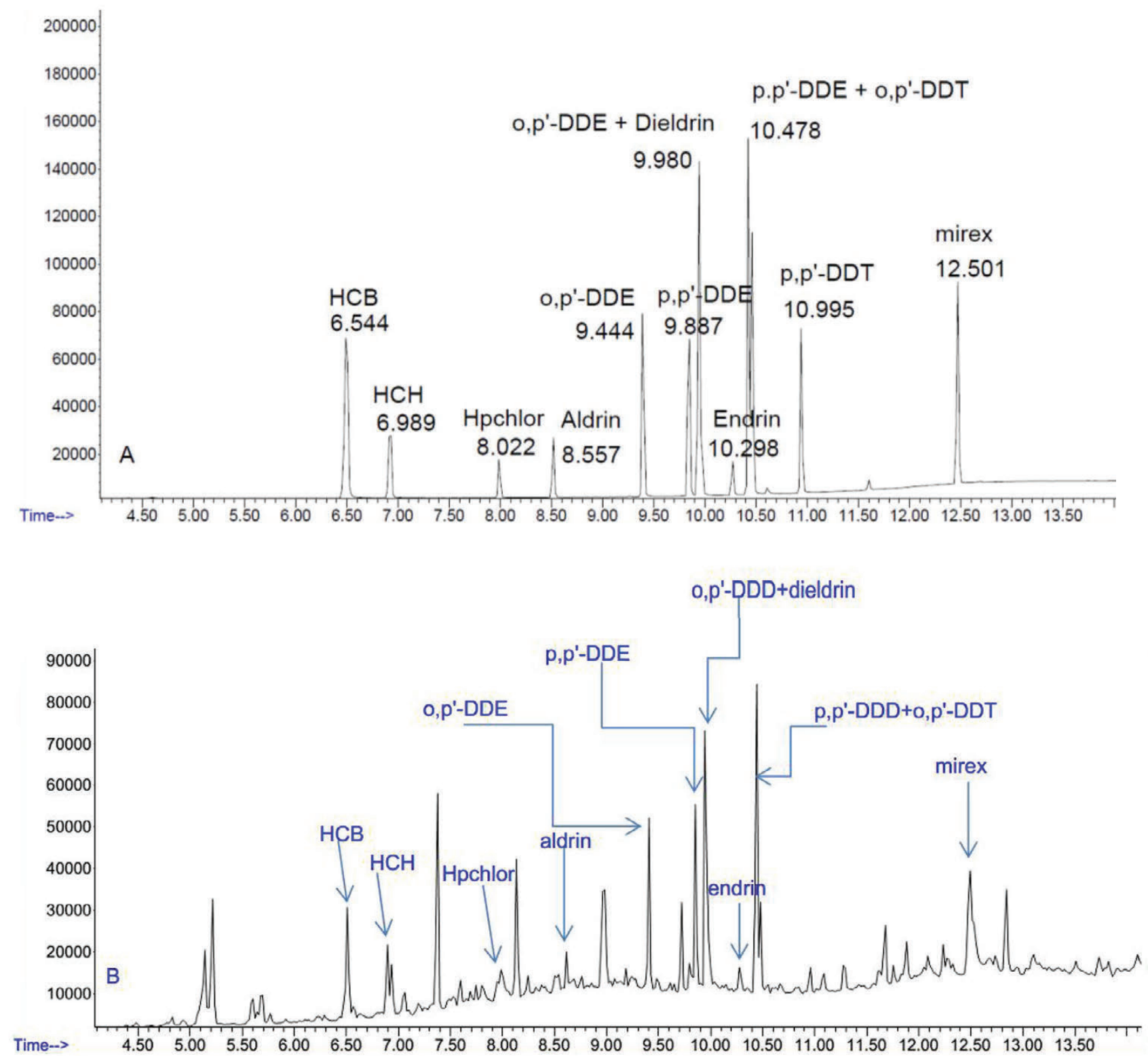

Figure A1

A) chromatogram of a $0.25 \mathrm{ppm}$ standard mixture of OCPs. B) chromatogram of clean water extract fortified with $0.125 \mathrm{ppm}$ of standards 

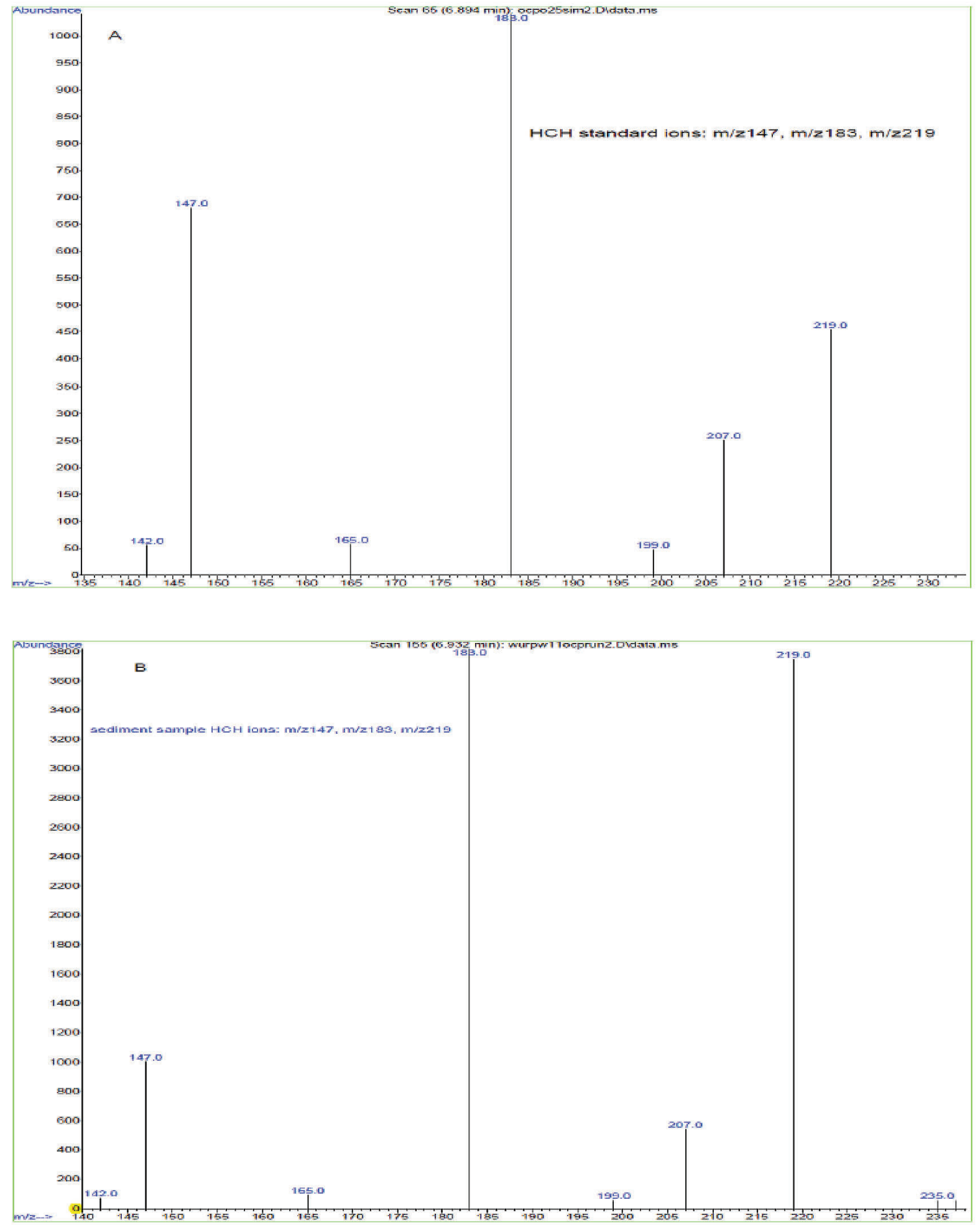

Figure A2

Example of fragment ions monitored in SIM mode: A) HCH standard ions. B) Sediment $\mathrm{HCH}$ ions 


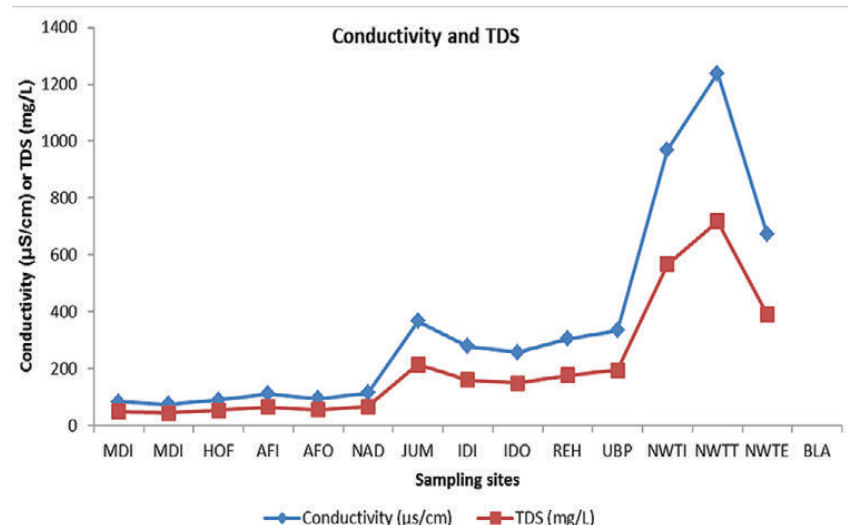

Figure A3

Conductivity and TDS in the water of uMngeni River

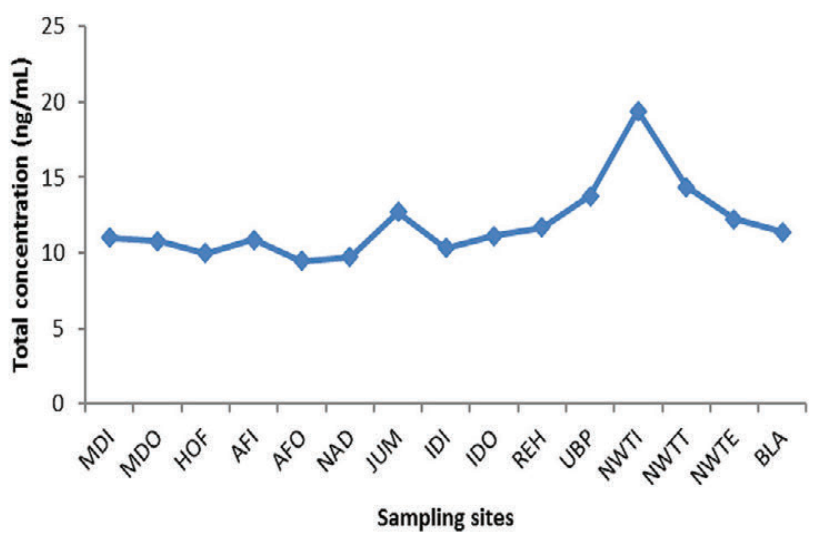

Figure A4

Trend of total concentration of OCPs in water across the sites

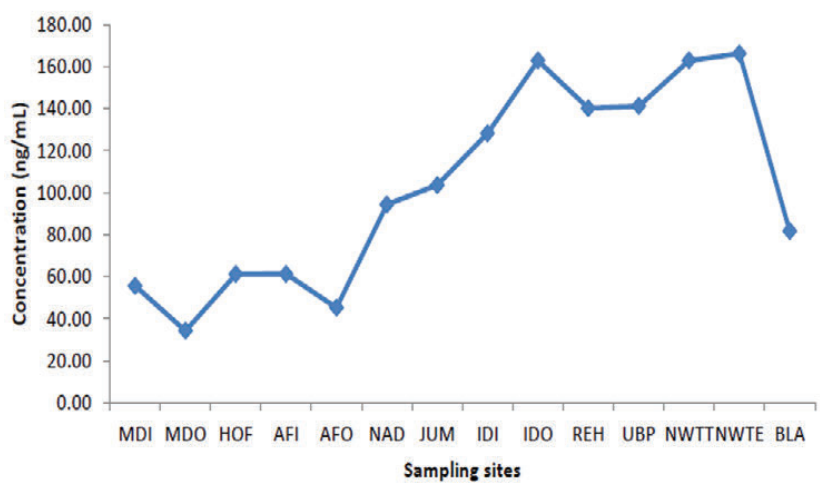

Figure A5

Trend of total concentration of OCPs in pore water across all sites
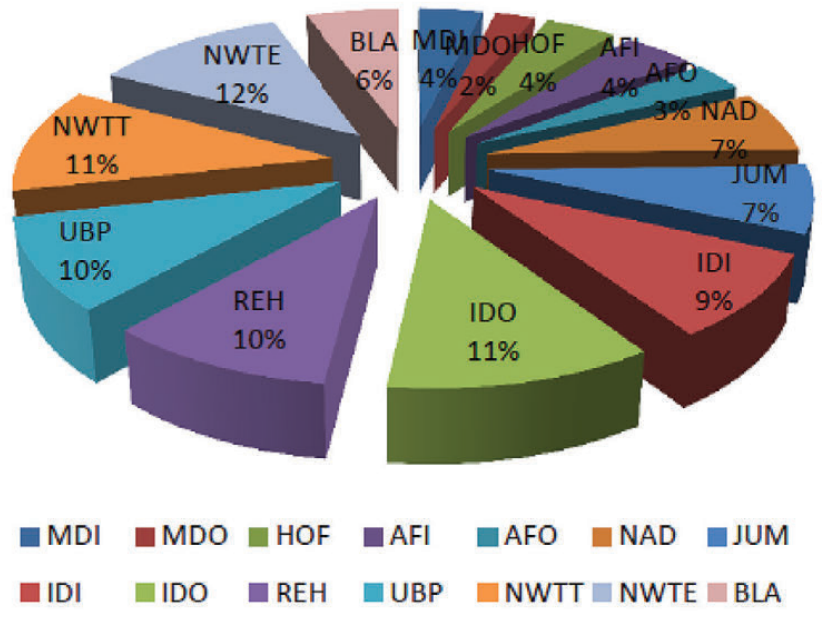

Figure A6

Per cent contribution of total concentration for sites for pore water sample

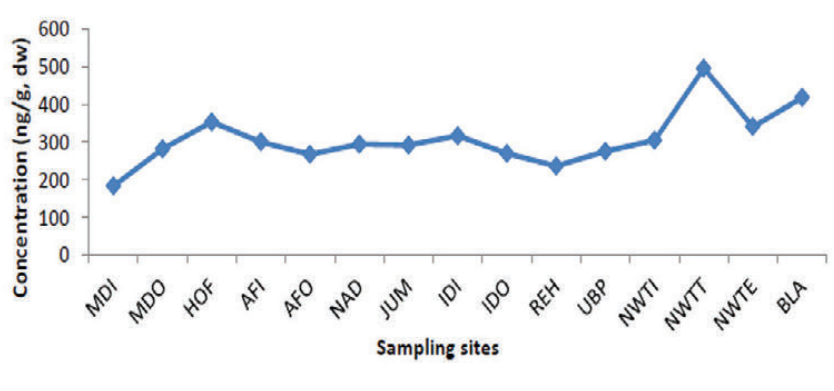

Figure $A 7$

Trend of the total concentration across sites for sediment samples

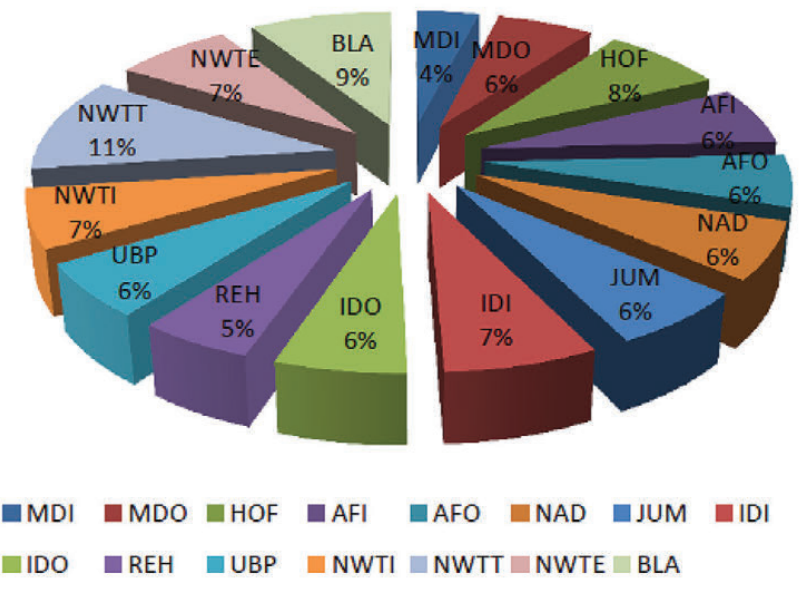

Figure $A 8$

Percentage contribution of the total concentrations in sediment at each site 


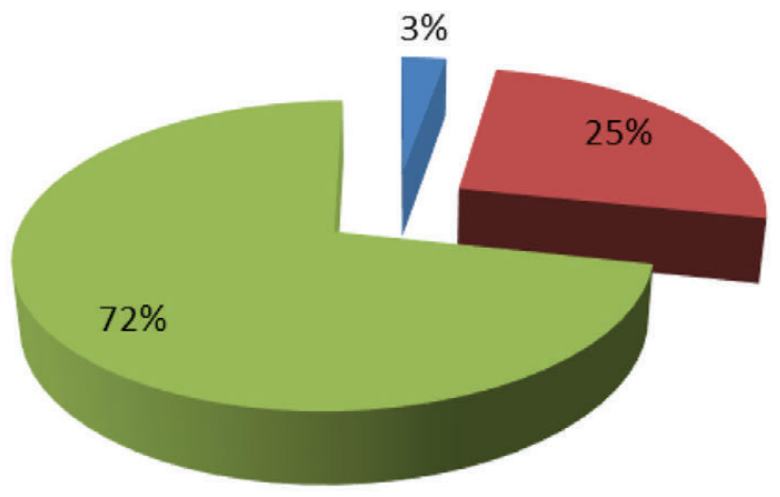

water $\quad$ pore water $\quad$ sediment

Figure A9

Per cent contribution of each matrix to the total average levels of OCPS

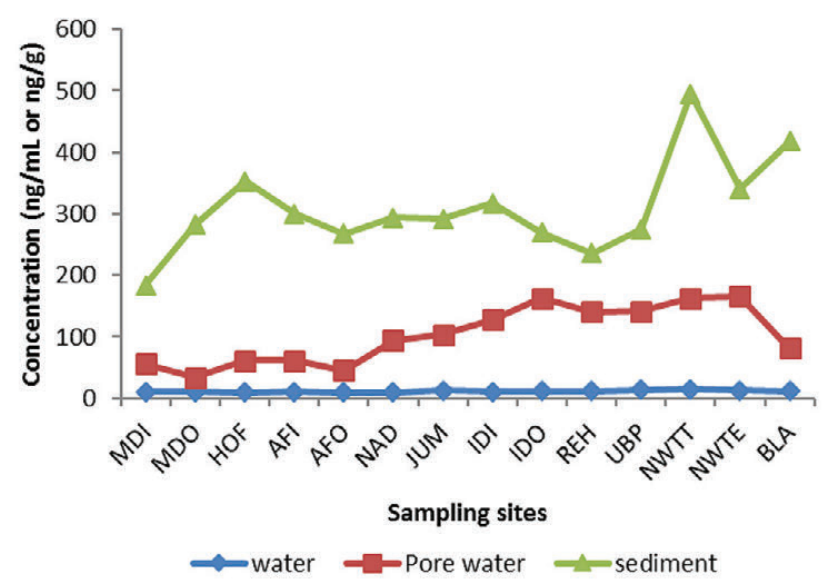

Figure A10

Trend of the total concentrations water, pore water and sediment

TABLE A1

Reduction of OCP concentrations in wastewater by the treatment process in the NWWTW (Northern Wastewater Treatment Works)

\begin{tabular}{|l|c|c|c|c|}
\hline OCPs & Influent conc. $(\mathbf{n g} / \mathrm{mL})$ & conc. after treatment $(\mathbf{n g} / \mathrm{mL})$ & difference & \% reduction \\
\hline HCB & 1.04 & 0.49 & 0.55 & 52.88 \\
\hline HCH & 1.26 & 0.64 & 0.62 & 49.21 \\
\hline heptachlor & 1.94 & 2.07 & -0.13 & -6.70 \\
\hline aldrin & 2.73 & 1.37 & 1.36 & 49.82 \\
\hline$o, p^{\prime}$-DDE & 2.32 & 1.58 & 0.74 & 31.90 \\
\hline$p, p^{\prime}$-DDE & 2.01 & 1.81 & 0.2 & 9.95 \\
\hline$o, p^{\prime}$-DDD/Dieldrin & 1.92 & 1.82 & 0.1 & 5.21 \\
\hline endrin & 3.48 & 1.53 & 1.95 & 56.03 \\
\hline$p, p^{\prime}$-DDD/o,p-DDT & 1.73 & 1.32 & 0.41 & 23.70 \\
\hline mirex & 1.02 & 1.74 & -0.72 & -70.59 \\
\hline
\end{tabular}




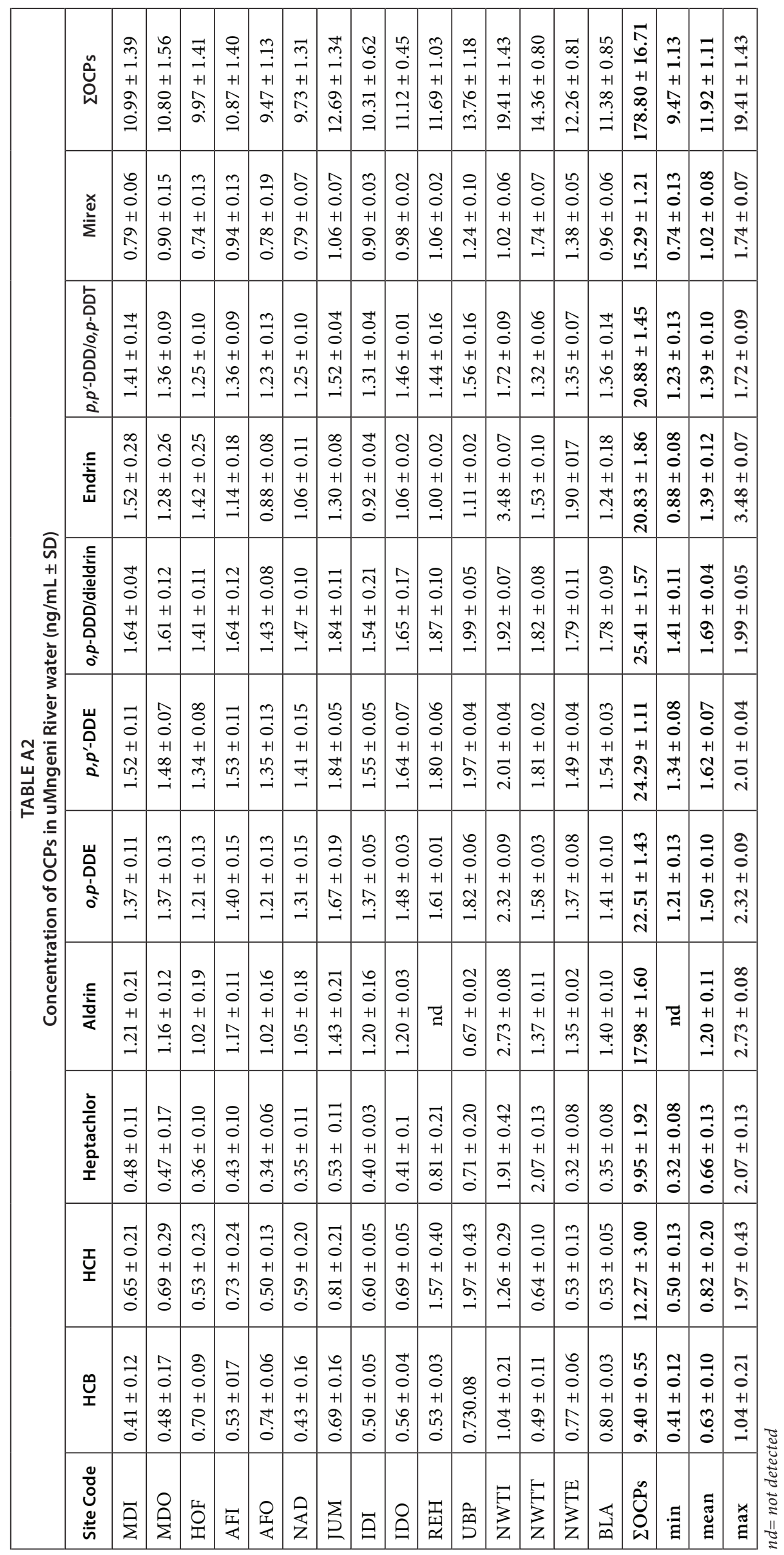




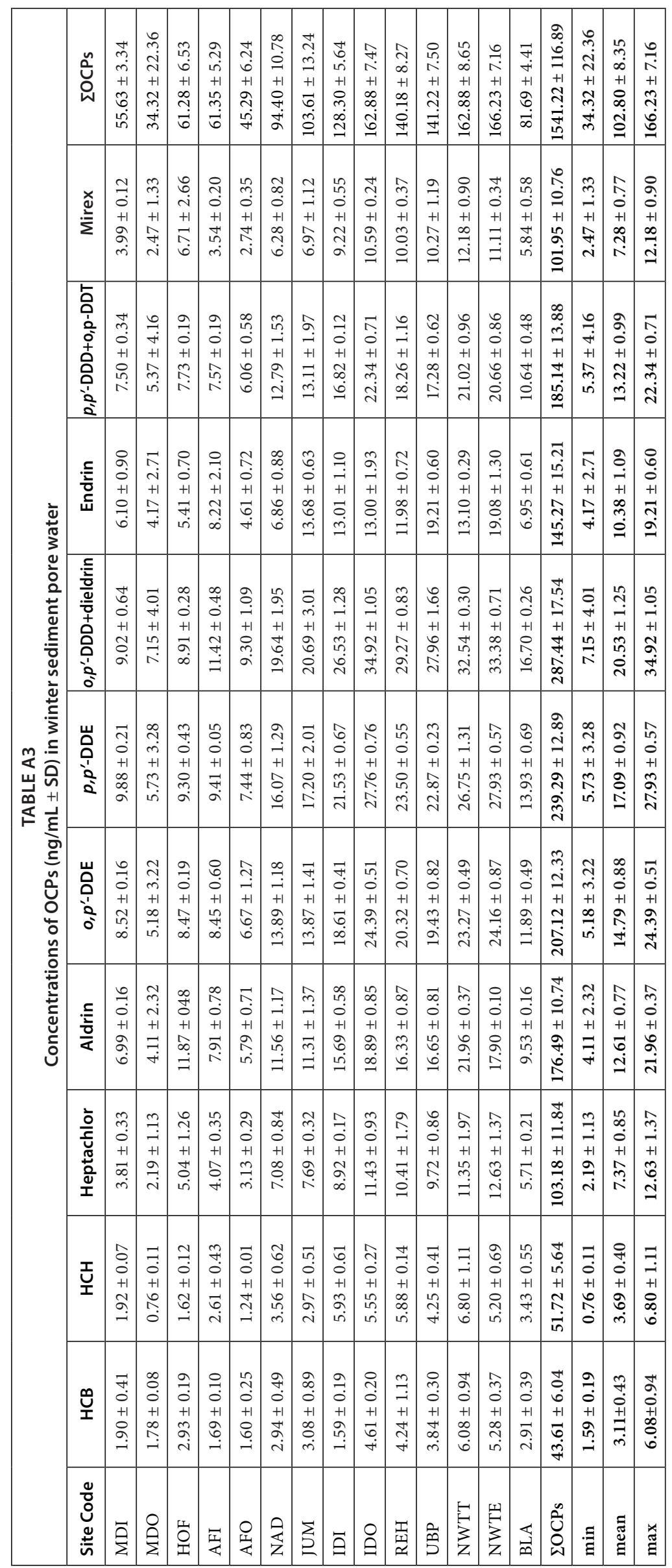




\begin{tabular}{|c|c|c|c|c|c|c|c|c|c|c|c|c|c|c|c|c|c|c|c|c|}
\hline & & $\begin{array}{l}1 \\
\infty \\
\infty \\
+ \\
+1 \\
0 \\
0\end{array}$ & 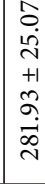 & 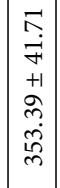 & $\mid \begin{array}{c}\tilde{\alpha} \\
+ \\
+ \\
+1 \\
\hat{n} \\
\hat{n} \\
\dot{0} \\
\tilde{r}\end{array}$ & 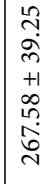 & 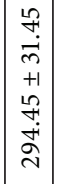 & 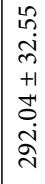 & 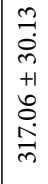 & $\begin{array}{l}0 \\
\dot{m} \\
+1 \\
\vec{\alpha} \\
\dot{0} \\
\vec{d}\end{array}$ & 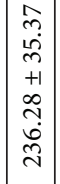 & 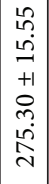 & 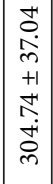 & 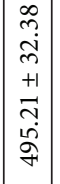 & 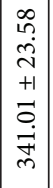 & $\begin{array}{l}1 \\
0 \\
\dot{0} \\
+ \\
+1 \\
\stackrel{7}{7} \\
\vec{y} \\
\Rightarrow\end{array}$ & 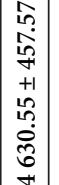 & $\begin{array}{l}\infty \\
\infty \\
\infty \\
+1 \\
0 \\
0 \\
0 \\
\infty \\
0\end{array}$ & $\begin{array}{l}0 \\
10 \\
0 \\
0 \\
+1 \\
0 \\
0 \\
0 \\
0 \\
0 \\
0\end{array}$ & \\
\hline & 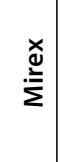 & $\begin{array}{c}+1 \\
\infty \\
\infty \\
\infty\end{array}$ & $\begin{array}{l}1 \\
i \\
+1 \\
0 \\
\infty \\
\infty \\
\alpha \\
\gamma\end{array}$ & 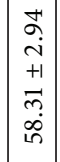 & 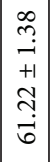 & 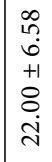 & 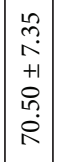 & $\begin{array}{l}\hat{\imath} \\
\hat{o} \\
+1 \\
\hat{o} \\
\dot{m}\end{array}$ & 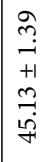 & $\begin{array}{l}\tilde{c} \\
\stackrel{+}{+} \\
+1 \\
+ \\
\tilde{m} \\
\dot{+}\end{array}$ & 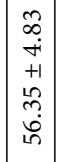 & $\mid \begin{array}{c}\infty \\
0 \\
i \\
+1 \\
\tilde{N} \\
\tilde{D} \\
i \\
i n\end{array}$ & 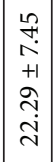 & 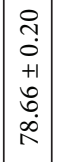 & 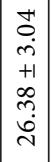 & 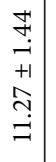 & 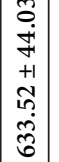 & $\begin{array}{l}\text { त̂ } \\
0 \\
+1 \\
\infty \\
\infty \\
\infty\end{array}$ & $\begin{array}{l}\vec{H} \\
\vec{i} \\
+1 \\
\vec{T} \\
\vec{H}\end{array}$ & \\
\hline & 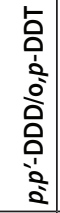 & $\begin{array}{l}\vec{b} \\
\dot{+} \\
+1 \\
\stackrel{0}{a} \\
\vec{a}\end{array}$ & $\begin{array}{l}0 \\
0 \\
0 \\
+1 \\
0 \\
\\
\end{array}$ & 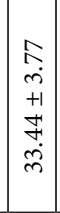 & \begin{tabular}{|c|c}
$\hat{N}$ \\
0 \\
+1 \\
+1 \\
$o$ \\
$\stackrel{\vec{d}}{v}$ \\
\end{tabular} & 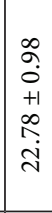 & 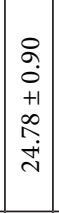 & $\begin{array}{l}\text { N } \\
0 \\
0 \\
+1 \\
0 \\
\stackrel{1}{2} \\
\end{array}$ & 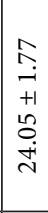 & 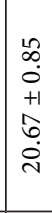 & 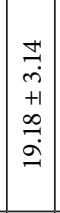 & 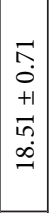 & 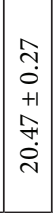 & $\mid \begin{array}{c}\infty \\
\stackrel{0}{0} \\
+1 \\
+1 \\
\infty \\
\stackrel{1}{\sim} \\
\sim\end{array}$ & $\begin{array}{c}\hat{0} \\
0 \\
+1 \\
+1 \\
\sigma \\
\infty \\
-\infty\end{array}$ & 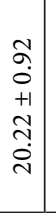 & 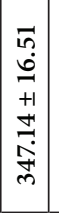 & $\begin{array}{c}\vec{r} \\
0 \\
+1 \\
\vec{n} \\
\infty \\
0\end{array}$ & 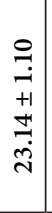 & \\
\hline & 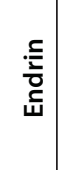 & 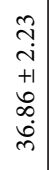 & 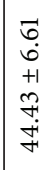 & 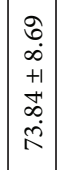 & $\begin{array}{l}2 \\
2 \\
i \\
+1 \\
2 \\
2 \\
0 \\
0 \\
\end{array}$ & \begin{tabular}{|l|}
0 \\
0 \\
$a$ \\
+1 \\
0 \\
0 \\
1 \\
0 \\
0
\end{tabular} & $\left|\begin{array}{c}\infty \\
\infty \\
\infty \\
+1 \\
+ \\
\hat{\infty} \\
\infty \\
\infty\end{array}\right|$ & 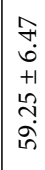 & $\begin{array}{l}2 \\
\grave{i} \\
i \\
+1 \\
\vec{n} \\
\infty \\
i\end{array}$ & 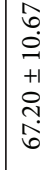 & 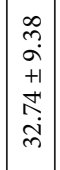 & 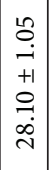 & 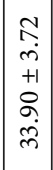 & 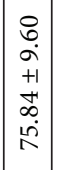 & 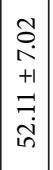 & 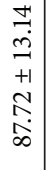 & 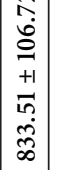 & 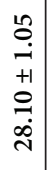 & $\begin{array}{l}= \\
7 \\
+1 \\
i \\
i n \\
i n \\
\text { in }\end{array}$ & \\
\hline $\begin{array}{l}3 \\
0 \\
\text { o }\end{array}$ & 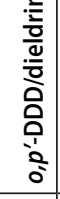 & $\begin{array}{l}\underset{+}{ \pm} \\
\stackrel{+}{+1} \\
+1 \\
0 \\
0 \\
\dot{\sim}\end{array}$ & 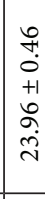 & 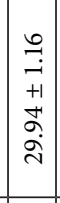 & 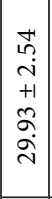 & 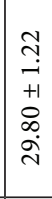 & $\left|\begin{array}{c}\stackrel{2}{0} \\
\stackrel{+}{+1} \\
+1 \\
i \\
i \\
i \\
\tilde{n}\end{array}\right|$ & 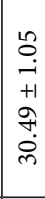 & $\begin{array}{l}\infty \\
0 \\
0 \\
+1 \\
+1 \\
0 \\
+ \\
\dot{j}\end{array}$ & 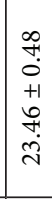 & 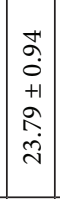 & 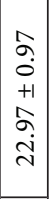 & 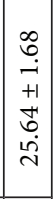 & $\left|\begin{array}{c}\vec{\infty} \\
\stackrel{0}{+} \\
+1 \\
\dot{+} \\
\dot{q} \\
\dot{d} \\
\dot{i}\end{array}\right|$ & 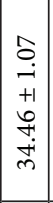 & 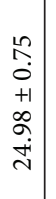 & 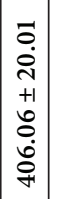 & $\begin{array}{l}\hat{a} \\
\dot{0} \\
+1 \\
\hat{\alpha} \\
\hat{\lambda}\end{array}$ & 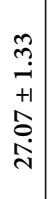 & \\
\hline 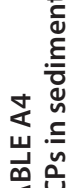 & $\begin{array}{c}\text { U. } \\
0 \\
\vdots \\
\vdots \\
\vdots\end{array}$ & $\left|\begin{array}{c}2 \\
0 \\
+1 \\
0 \\
0 \\
\dot{d}\end{array}\right|$ & 年 & $\left|\begin{array}{c}0 \\
i n \\
+ \\
+1 \\
+1 \\
+ \\
+ \\
\dot{m} \\
\dot{m}\end{array}\right|$ & 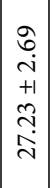 & 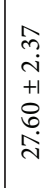 & 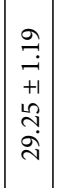 & $\begin{array}{l}0 \\
2 \\
o \\
+1 \\
+1 \\
f \\
i \\
j\end{array}$ & 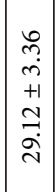 & $\begin{array}{l}\tilde{r} \\
i n \\
+1 \\
+1 \\
\tilde{r} \\
\tilde{n} \\
\tilde{n}\end{array}$ & 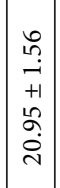 & 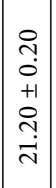 & 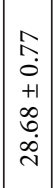 & $\mid \begin{array}{c}\vec{H} \\
i \\
+1 \\
+ \\
\mathbb{N} \\
\infty \\
\infty \\
\end{array}$ & 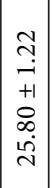 & $\mid$\begin{tabular}{c|}
0 \\
$\stackrel{2}{2}$ \\
$\stackrel{+}{+1}$ \\
$\hat{n}$ \\
$\stackrel{\sim}{\sim}$ \\
\end{tabular} & 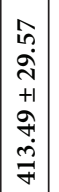 & $\begin{array}{c}m \\
\stackrel{0}{0} \\
+1 \\
\vdots \\
\dot{\lambda} \\
\dot{\lambda}\end{array}$ & 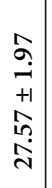 & $\begin{array}{c}\text { N } \\
\infty \\
\infty\end{array}$ \\
\hline 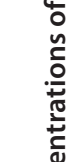 & $\begin{array}{l}\text { U. } \\
0 \\
0 \\
0 \\
0\end{array}$ & $\begin{array}{l}7 \\
0 \\
+1 \\
0 \\
0 \\
I\end{array}$ & 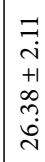 & 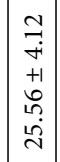 & 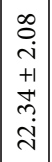 & 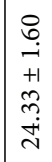 & 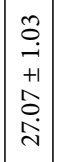 & 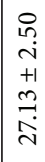 & 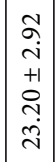 & $\begin{array}{l}\overrightarrow{3} \\
6 \\
+1 \\
+1 \\
\infty \\
\infty \\
\dot{n}\end{array}$ & 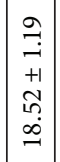 & 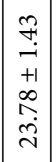 & 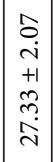 & 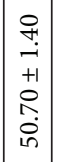 & $\begin{array}{c}0 \\
\infty \\
0 \\
+1 \\
0 \\
0 \\
0 \\
-1\end{array}$ & 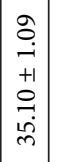 & 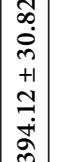 & $\begin{array}{l}\exists \\
0 \\
+1 \\
+1 \\
\infty \\
\\
-1\end{array}$ & 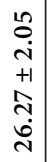 & $\begin{array}{l}\text { R. } \\
\text { in }\end{array}$ \\
\hline & $\frac{\frac{5}{\bar{t}}}{\frac{\bar{c}}{\alpha}}$ & 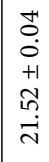 & 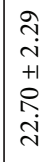 & 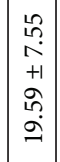 & 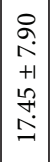 & $\begin{array}{l}\overrightarrow{+} \\
\stackrel{+}{+} \\
+ \\
+1 \\
\hat{y} \\
\infty \\
\infty\end{array}$ & 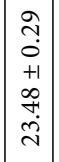 & 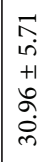 & \begin{tabular}{|c|}
$\vec{b}$ \\
$\vec{i}$ \\
+1 \\
$\vec{\infty}$ \\
$\vec{j}$ \\
$\vec{j}$
\end{tabular} & $\begin{array}{l}\overrightarrow{0} \\
+ \\
+1 \\
\infty \\
0 \\
\overrightarrow{2}\end{array}$ & $\mid \begin{array}{l}\infty \\
0 \\
\hat{i} \\
+1 \\
+1 \\
\tilde{i} \\
\tilde{i}\end{array}$ & 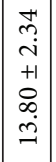 & 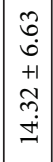 & \begin{tabular}{|l|}
$\vec{\sigma}$ \\
$\dot{b}$ \\
+1 \\
$\dot{0}$ \\
$\dot{0}$ \\
$\dot{m}$
\end{tabular} & 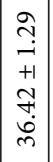 & $\mid \begin{array}{c}+ \\
\infty \\
i \\
+1 \\
\stackrel{+}{1} \\
\underset{m}{m}\end{array}$ & 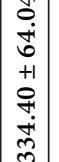 & 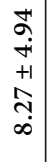 & 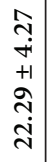 & d \\
\hline & 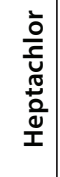 & $\mid \begin{array}{l}\infty \\
i \\
i \\
+1 \\
0 \\
0 \\
\dot{d} \\
\end{array}$ & 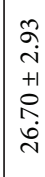 & $\mid \begin{array}{l}\tilde{i} \\
i \\
+1 \\
+ \\
0 \\
\dot{m} \\
\dot{m}\end{array}$ & $\mid \begin{array}{c}0 \\
\infty \\
\infty \\
+1 \\
\infty \\
\infty \\
0 \\
0 \\
0\end{array}$ & 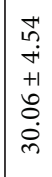 & 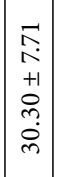 & $\begin{array}{l}0 \\
\sim \\
\infty \\
+ \\
+1 \\
0 \\
\dot{0} \\
\dot{m}\end{array}$ & $\mid \begin{array}{c}0 \\
i n \\
0 \\
0 \\
+1 \\
1 \\
0 \\
i \\
i \\
0\end{array}$ & $\begin{array}{l}\infty \\
\dot{m} \\
\dot{m} \\
+1 \\
+1 \\
\infty \\
\infty \\
\infty \\
-\end{array}$ & $\mid \begin{array}{c}0 \\
0 \\
\dot{d} \\
+1 \\
0 \\
0 \\
0 \\
\infty \\
-1\end{array}$ & $\mid \begin{array}{c}0 \\
0 \\
0 \\
+1 \\
+1 \\
\vec{m} \\
\vec{q} \\
\end{array}$ & $\mid \begin{array}{l}20 \\
0 \\
+1 \\
+1 \\
20 \\
0 \\
0 \\
0\end{array}$ & 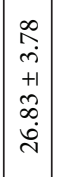 & $\mid \begin{array}{c}0 \\
0 \\
\sim \\
+1 \\
+1 \\
\sim \\
\stackrel{\sim}{\sim} \\
\mid\end{array}$ & $\left|\begin{array}{c}\tilde{D} \\
\tilde{n} \\
+1 \\
\hat{1} \\
\hat{D} \\
i\end{array}\right|$ & 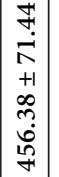 & $\begin{array}{l}\hat{b} \\
\dot{n} \\
+1 \\
0 \\
+ \\
+ \\
\infty \\
\rightarrow\end{array}$ & 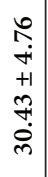 & $\begin{array}{l}\hat{\hat{A}} \\
\text { in }\end{array}$ \\
\hline & $\underset{\mathrm{U}}{\mathbf{I}}$ & $\begin{array}{l}0 \\
0 \\
+1 \\
+1\end{array}$ & $\begin{array}{l}\tilde{S} \\
+ \\
+ \\
+1\end{array}$ & 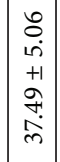 & $\begin{array}{c}\sim \\
\vec{m} \\
+1 \\
+1 \\
\vec{j} \\
\vec{\sim}\end{array}$ & $\begin{array}{l}+ \\
\infty \\
0 \\
\dot{0} \\
+1 \\
+\infty \\
\dot{\infty} \\
\dot{m}\end{array}$ & $\mid \begin{array}{c}0 \\
\mathbf{T} \\
+ \\
+1 \\
\infty \\
0 \\
\infty \\
\infty\end{array}$ & $\begin{array}{l}\stackrel{\overbrace{}}{1} \\
\stackrel{+}{+1} \\
\stackrel{+}{+} \\
\stackrel{+}{+}\end{array}$ & 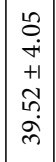 & 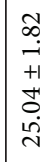 & $\mid \begin{array}{l}\infty \\
\infty \\
\infty \\
+1 \\
0 \\
\infty \\
\dot{0} \\
0\end{array}$ & $\mid \begin{array}{c}\vec{m} \\
\overrightarrow{+} \\
++ \\
\overrightarrow{+} \\
\overrightarrow{\vec{\psi}} \\
\end{array}$ & $\begin{array}{c}\stackrel{n}{\sim} \\
\stackrel{+}{+} \\
+1 \\
+\infty \\
\infty \\
\infty \\
\infty \\
\infty\end{array}$ & 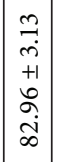 & 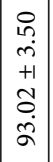 & $\mid \begin{array}{c}\mathcal{N} \\
\hat{i} \\
+1 \\
\hat{f} \\
\infty \\
\infty \\
\end{array}$ & 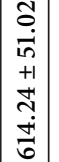 & $\begin{array}{c}\vec{a} \\
0 \\
+1 \\
+ \\
\stackrel{+}{+}\end{array}$ & 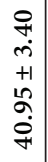 & 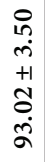 \\
\hline & $\overrightarrow{\mathrm{I}}$ & t? & 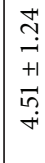 & $\mid \begin{array}{l}0 \\
0 \\
+1 \\
+1 \\
2 \\
0 \\
0 \\
0\end{array}$ & 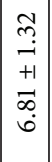 & 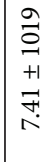 & 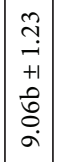 & 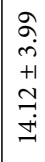 & $\mid \begin{array}{c}\infty \\
\tilde{i} \\
i \\
+1 \\
0 \\
0\end{array}$ & 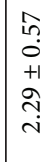 & 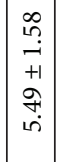 & 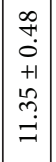 & 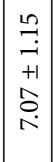 & 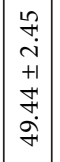 & $\mid$\begin{tabular}{c}
$q$ \\
\multirow{2}{0}{} \\
+1 \\
+1 \\
$\hat{h}$ \\
0 \\
0
\end{tabular} & 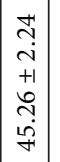 & $\mid \begin{array}{c}\tilde{m} \\
\tilde{n} \\
+1 \\
+1 \\
0 \\
\stackrel{0}{0} \\
\stackrel{2}{2}\end{array}$ & $\begin{array}{l}\text { in } \\
0 \\
+1 \\
\text { ते } \\
\text { in }\end{array}$ & 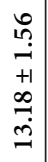 & 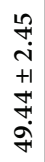 \\
\hline & 8 & & & & & & $\begin{array}{l}\vec{z} \\
z\end{array}$ & & & & 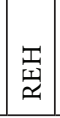 & 登 & 3 & 3 & z & & & 寻 & ฮ్๊ & \\
\hline
\end{tabular}

